\title{
Chapter 3 \\ Identification of Health Risk Factors and Their Parameters
}

\begin{abstract}
This chapter highlights the importance of identifying health risk factors and their parameters for healthier built environments. In Sect. 3.1, epidemiological terms such as "determinants of health", "health risk" and "health hazards", are introduced. In Sect. 3.2, health risk factors and their main parameters in built environments are further identified and classified into six groups: biological, chemical, physical, psychosocial, personal, and others. Detailed definition of health risk factors and their main parameters, followed by the results of epidemiological studies proving the association between potential health outcomes and health risk factors, are described in Sects. 3.3, 3.4, 3.5, 3.6 and 3.7. Identified and classified health risk factors and their parameters are the basis for the identification of single and multi-group interactions among them, described in Chap. 4.
\end{abstract}

\subsection{Determinants of Health, Health Risk, and Health Hazard Factors}

Whether people are healthy or not is determined by their circumstances and environment. WHO defines health risk factors from built environments, genetics, income and education levels, and relationships with friends and family. All these factors have considerable impacts on health, while other more commonly considered factors, such as access and use of health care services, often have less of an impact (WHO 2017a).

The determinants of built environments include:

\section{- Physical environment,}

- Social and economic environment, and

- Person's individual characteristics and behaviours.

Individuals often cannot control many of the determinants of health in built environments (Table 3.1).

"Risk" and "hazard" are terms commonly used to describe aspects of the potential harm to health. The terms "health risk" and "health hazard" are often not 
Table 3.1 Determinants of health in built environments (WHO 2017a)

\begin{tabular}{|c|c|}
\hline Determinants of health & Link to health \\
\hline Physical environment & $\begin{array}{l}\text { Safe water and clean air, healthy workplaces, safe houses, } \\
\text { communities and roads all contribute to good health }\end{array}$ \\
\hline Income and social status & $\begin{array}{l}\text { Higher income and social status are linked to better health. The } \\
\text { greater the gap between the richest and poorest people, the greater } \\
\text { the differences in health }\end{array}$ \\
\hline Education & $\begin{array}{l}\text { Low education levels are linked to poor health, more stress, and } \\
\text { lower self-confidence }\end{array}$ \\
\hline $\begin{array}{l}\text { Employment and } \\
\text { working conditions }\end{array}$ & $\begin{array}{l}\text { People with employment are healthier, particularly those who } \\
\text { have more control over their working conditions }\end{array}$ \\
\hline Social support networks & $\begin{array}{l}\text { Greater support from families, friends and communities is linked } \\
\text { to better health }\end{array}$ \\
\hline $\begin{array}{l}\text { Personal behaviour and } \\
\text { coping skills }\end{array}$ & $\begin{array}{l}\text { Eating habits, level of physical activity, smoking, drinking, and } \\
\text { how we deal with life's stresses and challenges all affect health }\end{array}$ \\
\hline Culture & $\begin{array}{l}\text { Customs, traditions, and the beliefs of the family and community } \\
\text { all affect health }\end{array}$ \\
\hline Genetics & $\begin{array}{l}\text { Inheritance plays a part in determining lifespan, healthiness, and } \\
\text { the likelihood of developing certain illnesses }\end{array}$ \\
\hline Gender & $\begin{array}{l}\text { Men and women suffer from different types of diseases at different } \\
\text { ages }\end{array}$ \\
\hline Health services & $\begin{array}{l}\text { Access to and use of services that prevent and treat disease } \\
\text { influence health }\end{array}$ \\
\hline
\end{tabular}

properly used. The term "risk" is the "likelihood that a person may be harmed or suffers adverse health effects if exposed to a hazard" (HSA 2017).

The level of risk is often categorized according to the potential harm or adverse health effect that the hazard may cause, how many times a person is exposed, and the number of persons exposed (HSA 2017). Health hazards frequently occur in all built environments. They may be in the form of chemical hazards (e.g., chlorine or a pesticide), biological hazards (e.g., fungi in damp buildings), physical hazards (e.g., excessive noise, coldness, over-heating or radiation), ergonomic hazards (e.g., unhealthy body positions and repetitive strain) and psychological hazards (e.g., anxiety) (Safeopedia 2017).

\section{BOX 3.1 Health risk}

The term "health risk" is defined as something that could cause harm to people's health (Collins 2017a, b). The Environmental Protection Agency (EPA 2016) considers risk to be: "The chance of harmful effects to human health or to ecological systems resulting from exposure to an environmental stressor". Therefore, a human health risk is described as: "The likelihood that a given exposure or series of exposures may have damaged or will damage the health of individuals" (EPA 2016). 


\section{BOX 3.2 Health hazard}

A health hazard is defined as something that is dangerous to health. The most common definition of a health hazard is: "a potential source of harm or adverse health effect on a person(s)". For example, a place is structurally unsafe (Collins 2017b; HSA 2017).

For example, the leading global risks for mortality in the world are high blood pressure (responsible for $13 \%$ of deaths globally), tobacco use (9\%), high blood glucose $(6 \%)$, physical inactivity (6\%), and overweight and obesity (5\%) (WHO 2009a). As a country develops, the types of diseases that affect a population shift from primarily infectious illnesses, such as diarrhoea and pneumonia, to primarily noncommunicable illnesses, such as cardiovascular disease and cancers (WHO 2009a). Many diseases are caused by multiple risk factors, and individual risk factors may interact in their impact on the overall risk of disease. As a result, attributable fractions of deaths and burden for individual risk factors usually overlap and often add up to more than $100 \%$ (WHO 2009a). A prime example of this is that two risk factors - smoking and radon - cause lung cancer. Exposure to radon is the second leading cause of lung cancer (EPA 2017a). The risk is significantly higher for smokers than for non-smokers. Globally, more than $85 \%$ of radon-induced lung cancer deaths are among smokers. The optimal strategy for the elimination of the public health burden of radon includes building design strategies with remediation, residential radon testing as well as smoking prevention (Lantz et al. 2013).

Some risk factors can be changed, such as unhealthy lifestyle habits and environments. Other risk factors, such as age, family history and genetics, race and ethnicity, and sex, cannot be changed. Healthy lifestyle changes as well as a healthy environment can decrease your risk for developing some diseases (NIH 2017). It is clear that many environmental factors can affect health. For example, some of the more important significant risk factors are unsafe neighbourhoods, access to unhealthy food, limited access to recreational facilities or parks, low socioeconomic status, unhealthy social environment, unsafe water, sanitation and low hygiene, poor quality of air (WHO 2017b).

\section{BOX 3.3 Risk factor}

A risk factor is any attribute, characteristic or exposure of an individual that increases the likelihood of developing a disease or injury (WHO 2017b).

With the purpose of designing healthy built environments and taking into account previous definitions (WHO 2017b), the term "health risk factor in built environments" is defined: 


\section{BOX 3.4 Health risk factors in built environments}

Health risk factors in built environments are all risk factors that are present in built environments, namely living and working environments, indoors or outdoors. A given exposure or series of exposures to them may have damaged or will damage the health of individuals. For example, increased noise levels and lack of daylight in a built environment are parameters in the group of physical risks factors; formaldehyde, phthalates in the air are parameters in the group of chemical health risk factors. Therefore, identification of health risks factors and their parameters in built environments is the key activity for effective control and prevention of health.

The standard CAN/CSA-Z1002-12 (2017) - Occupational health and safetyHazard identification and elimination and risk assessment and control uses the following epidemiological terms: harm- "physical injury or damage to health" (CAN/CSA-Z1002-12 2017) and hazard: "a potential source of harm to a worker" (CAN/CSA-Z1002-12 2017).

Identification of health hazards and risk factors in built environments is a key activity for effective control and prevention against them and is the first step in a process called health risk assessment (HRA). The Centers for Disease Control and Prevention (CDC 2009) define an HRA as: "a systematic approach to collecting information from individuals that identifies risk factors, provides individualized feedback, and links the person with at least one intervention to promote health, sustain function and/or prevent disease."

\section{BOX 3.5 Health risk assessment}

Health risk assessment is the process of estimating the nature and probability of adverse health effects in humans who may be exposed to chemicals in contaminated environmental media, now or in the future (EPA 2016).

The EPA uses health risk assessments to characterize the nature and magnitude of health risks to human beings (e.g., residents, workers, recreational visitors) and ecological receptors (e.g., birds, fish, wildlife) from chemical contaminants and other stressors that may be present in the environment.

The main steps of HRA (HSA 2017) for the prevention and control of health risk factors in built environments:

- Identification of hazards and risk factors that have the potential to cause harm (hazard identification) to humans and/or ecological systems regarding health.

- Analysis and evaluation of the risk in association with that hazard (risk analysis, and risk evaluation). Which includes: 
- Dose-Response Assessment: relationship between exposure and effects

- Exposure Assessment: frequency, timing, and levels of contact with the potential hazard

- Risk Characterization: summary of an overall conclusion about risk, how well the data support conclusions about the nature and extent of the risk from exposure to potential hazard

- Determining appropriate ways to eliminate the hazard, or control the risk when the hazard cannot be eliminated (risk control).

Risk control includes actions that can be taken to reduce the exposure to the potential hazard. Alternatively, the control could be implemented to remove the hazard or to reduce the likelihood of the risk by reducing the exposure to that hazard (HSA 2017). Actions are listed hierarchically from the most preferred to least preferred (1-6):

1. Elimination of the hazards (e.g., removal of dangerous substance from construction materials),

2. Substitution of the hazards with those of lower risk (e.g., usage of less toxic substitutes),

3. Isolation of the hazard (e.g., noise-isolated room for noisy equipment),

4. Engineering approaches to the hazards (e.g., redesigning a process to place a barrier between the person and the hazard),

5. Administrative approaches to the hazards (e.g., adopting safe work practices, training to reduce the potential for harm and/or adverse health effects to people),

6. Usage of personal protective equipment.

In the framework of HRA, health risk factors and their main parameters in built environments are identified and classified in Sect. 3.2.

\subsection{Identification and Classification of Health Risk Factors in Built Environments and Their Parameters}

During the time spent indoors, people are exposed to numerous health risk factors, exposure to which can affect human health. The extent of the effects depends on their exposure dose, exposure time, type of pollutants, and people's individual characteristics (Yassi et al. 2001). Health risk factors in built environments can be classified in various ways, according to the purpose of classification. The most common classification of health risk factors was defined in the book on "Basic Environmental Health" by Yassi et al. (2001):

- Biological risk factors,

- Chemical risk factors,

- Physical risk factors, and

- Psychosocial, personal and other risk factors. 


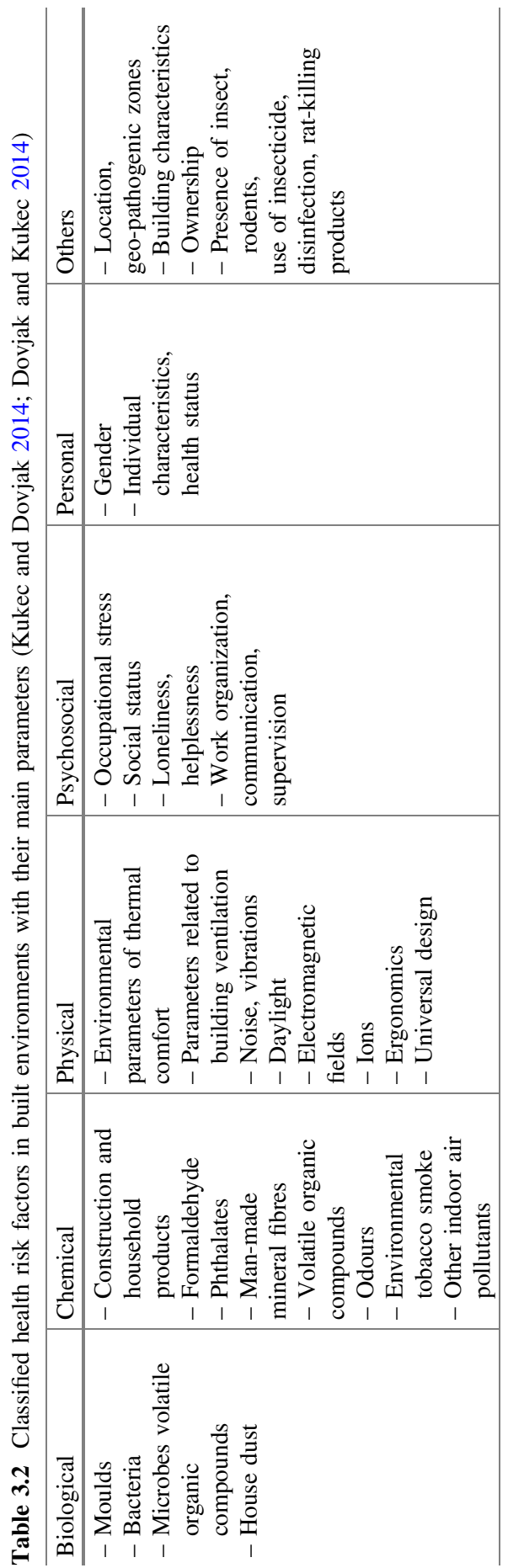


On the basis of a comprehensive systematic literature review of 96 scientific articles published between 1974 and 2014 (Kukec and Dovjak 2014; Dovjak and Kukec 2014), key parameters within every group of health risk factors are identified and classified (Table 3.2).

In Sects. 3.3-3.7, detailed determinants of health risk factors and their main parameters are provided, followed by the results of epidemiological studies proving the association between potential health outcomes and health risk factors in built environments.

\subsection{Association Between Potential Health Outcomes and Physical Health Risk Factors in Built Environments}

The most researched parameters in the group of physical risk factors in built environments are those of thermal comfort, building ventilation, noise, vibration, daylight, electromagnetic fields, ions, as well as ergonomic issues and universal design. Deviations of one or several physical health risk factors from the optimal values may result in various health outcomes.

Environmental parameters of thermal comfort and thermal stress are physical quantities connected with the environment: air temperature, mean radiant temperature, absolute air humidity, air velocity and surface temperature (ISO 7726: 1998). In addition to environmental parameters, metabolic rate and clothing also have a direct impact on a person's perception of thermal comfort.

Environmental parameters of thermal comfort that deviate from optimal values result in uncomfortable or even in unhealthy conditions (Prek and Butala 2012). Studies show that general dissatisfaction with the indoor air temperature and indoor air humidity may be related to the increase of SBS (Sick Building Syndrome) symptoms (Valbjorn and Kousgaard 1986; Valbjorn and Skov 1987). Jaakkola et al. (1989) carried out a study in a modern eight-floor office building in Finland ( $\mathrm{N}=2,150$ workers $)$ and found a linear correlation between the amount of SBS symptoms, sensation of dryness, and a rise in air temperature above $22{ }^{\circ} \mathrm{C}$. SBS symptoms increased both when the indoor air temperature was considered to be too cold and too warm.

Nordström et al. (1994) performed a study in new and well-ventilated geriatric hospital units in southern Sweden ( $\mathrm{N}=104$ employees). It was stated that in Scandinavia, the indoor relative humidity in well-ventilated buildings in winter was usually in the range between 10 and 35\%, which resulted in increased numbers of dissatisfied persons. It was concluded that air humidification during the heating 
season in colder climates can decrease the symptoms of SBS and the perception of dry air among employees. Lim et al. (2015) studied the association between SBS symptoms and some potential risk factors in an office environment (selected personal factors, office characteristics and indoor office exposures) among office workers $(\mathrm{N}=695)$ from a Malaysian university. The weekly prevalence of dermal, mucosal and general symptoms of SBS was $11.9 \%, 16.0 \%$ and $23.0 \%$, respectively. The SBS symptoms occurring among the workers in the offices were associated with low relative air humidity $(\mathrm{p}=0.04$; the association was statistically significant) and high air temperature in the office ( $p=0.05$; the association was statistically significant). Andersen et al. (1974) performed an experiment in a climate chamber, in which eight healthy young men were exposed to clean dry air with a temperature of $23{ }^{\circ} \mathrm{C}$. The experiment showed that very low indoor relative humidity (less than 20\%) can cause drying of the mucous membranes and of the skin in some individuals.

\section{BOX 3.6 p-value (probability)}

The probability that a test statistic would be as extreme as observed or more extreme if the null hypothesis were true. Letter $\mathrm{p}$ stands for this probability. Investigators may arbitrarily set their own significance levels, but in most biomedical and epidemiological works, a study result in which the p-value is less than $5 \%(\mathrm{p}<0.05)$ or $1 \%(\mathrm{p}<0.01)$ is considered sufficiently unlikely to have occurred by chance to justify the designation "statistically significant" (Porta 2008).

\section{BOX 3.7 Relative risk (RR) and Odds ratio (OR)}

$\mathbf{R} \mathbf{R}$ is the ratio between the risk of an event among the exposed and the risk among the unexposed; this usage is synonymous with risk ratio. OR is a measure of association between an exposure and an outcome. The OR represents the odds that an outcome will occur given a particular exposure, compared to the odds of the outcome occurring in the absence of that exposure. OR/RR = 1 Exposure does not affect the odds of outcome; OR/ $\mathrm{RR}>1$ Exposure associated with higher odds of outcome; OR/RR $<1$ Exposure associated with lower odds of outcome (Porta 2008).

High indoor air humidity usually appears in buildings located in a hot-humid climate. However, higher indoor relative humidity (more than $80 \%$ ) may also occur in other buildings, especially due to incorrectly designed building envelopes, systems and installations, processes of increased steam production, water damage, and flooding. These conditions may lead to dampness, stuffy odour, visible mould, and adverse health effects. Dampness may be a strong predictor of SBS symptoms. Li et al. (1997) evaluated the association between measures of dampness and 
symptoms of respiratory illness in 612 employees in 56 day-care centres in the Taipei, Taiwan area. Dampness was found in $75.3 \%$ of the centres, visible mould in $25.8 \%$, stuffy odour in $50.0 \%$, water damage in $49.3 \%$, and flooding in $57.2 \%$. Furthermore, the prevalence of SBS symptoms in the day-care workers was statistically significant among those who worked in centres that had mould or dampness.

Additionally, lower surface temperatures may result in local discomfort, radiative asymmetry, and water condensation. Studies made by Barna and Bánhidi (2012) showed that low surface temperatures often result in thermally uncomfortable conditions and the higher prevalence of SBS symptoms. Amin et al. (2015) investigated thermal conditions and SBS symptoms in three air-conditioned engineering education laboratories located at University Tun Hussein Onn Malaysia ( $\mathrm{N}=71$ undergraduate and postgraduate students). The results show that the mean radiant temperature was not within the recommended range (minimum $17.8{ }^{\circ} \mathrm{C}$, maximum $22.42{ }^{\circ} \mathrm{C}$ ). A subjective measurement with questionnaire surveys was also performed. Among the symptoms present due to unacceptable thermal conditions in all laboratories, dry skin was the most common $(40.85 \%)$, followed by runny nose $(31 \%)$, dry eyes $(29.58 \%)$, blocked/stuffy nose $(28.17 \%)$, tiredness $(26.76 \%)$ and flu-like symptoms $(21.13 \%)$.

Inadequate ventilation is associated with the accumulation of a variety of pollutants from building materials and indoor activities, dampness, and with a higher risk of airborne infectious disease transmission among the occupants. Identifying and controlling common indoor air pollutants can protect human health.

The general purpose of ventilation in buildings is to provide healthy air for breathing by diluting the pollutants originating from the building itself and activities performed in the building and removing the pollutants from it (Awbi 2003).

Norhidayah et al. (2013) studied the association between indoor air quality (IAQ) parameters and symptoms of SBS in three selected buildings. The findings suggested that important predictors of sick building syndromes are ventilation and the accumulation of possible contaminants within the indoor environment. Other studies emphasized that the main causes for the SBS symptoms related to building ventilation are inadequate functioning, obsolete and inadequately maintained HVAC systems, decreased number of air changes and decreased volume of clean air (ECA 1989). A literature review of 41 studies (Seppänen et al. 1999) showed that ventilation rates below $10 \mathrm{~L} / \mathrm{s}$ per person in office buildings were associated with statistically significant worsening in one or more health or perceived air quality outcomes. Some studies determined that increases in ventilation rates up to approximately $20 \mathrm{~L} / \mathrm{s}$ per person were associated with significant decreases in the prevalence of the SBS symptoms or with significant improvements in perceived IAQ. The reviewed studies reported RR of 1.5-2.0 for respiratory 
illnesses and RR of 1.1-6.0 for the SBS symptoms for low compared to high ventilation rates.

A literature review by Carrer et al. (2015) estimated the minimum ventilation rates for which no effects on some health outcomes were observed. The lowest ventilation rates for which no adverse effects were seen for respiratory symptoms, asthma or allergy symptoms, airborne infectious diseases or acute health symptoms (SBS/BR symptoms) were about 6-7 L/s per person. In terms of effects on short-term absence rates and performance and learning, these minimum rates are much higher, ranging from 16-24 L/s per person. If the lowest ventilation rates for which no adverse effects were seen were selected based on building type, then the ventilation rates in homes and dormitories would be 6-7 L/s per person, in schools $12 \mathrm{~L} / \mathrm{s}$ per person and in offices $25 \mathrm{~L} / \mathrm{s}$ per person.

Numerous researchers have examined the prevalence of SBS symptoms in naturally ventilated and air-conditioned buildings. A literature review on the ventilation of office buildings (Seppänen and Fisk 2002) indicated that occupants of naturally ventilated offices had fewer SBS symptoms than occupants of air-conditioned offices did. A similar study was performed by Costa and Brickus (2000) in a central-air-conditioned shopping centre and in natural ventilated commercial shops in Rio de Janeiro, Brazil. Air-conditioned buildings were associated with increased SBS symptoms.

Noise is unwanted sound judged to be unpleasant, loud or disruptive to hearing (WHO 2013). Exposure to noise in built environments has several harmful impacts on health: disturbed sleep, cardiovascular and psychophysiological effects, and reduced performance, as well as provoking annoyance responses and changes in social behaviour.

Excessive noise seriously harms human health and interferes with people's daily activities (WHO 2013). Wonga (2009) studied the prevalence of SBS among apartment residents of 748 households in Hong Kong. The major indoor environmental quality problem perceived by the residents was noise. In addition to excessive noise, low-frequency noise $(20-100 \mathrm{~Hz})$ may also cause health problems. Low-frequency noise is found in buildings with industrial machines or ventilation machinery. Certain body organs, specifically the eyes, have characteristic resonance frequencies in the range of 1-20 Hz (ECA 1989). Hodgson et al. (1987) observed that irritability and dizziness experienced by a group of secretaries working in new offices correlated significantly with the vibrations measured on their desks. The vibrations were caused by an adjacent pump room.

Lighting in buildings, especially daylight, should be designed for the visual needs of the users and their expected tasks within a given active space as well as non-visual effects (Webb 2006). 
Many studies have found some potential health consequences due to a lack of daylight in built environments. Nicklas and Bailey (1997) performed some analyses of the performance of students in daylit schools. They compared two groups of students from elementary schools in Alberta, Canada: the first group attending a school with full-spectrum light, the second group attending a similar school with normal lighting conditions. The results showed that the first group of students were healthier and attended school 3.2-3.8 days more per year; full-spectrum light induced more positive moods in students. Because of the additional vitamin D received by the students in the first group, they had 9 times less dental decay, and they were $2.1 \mathrm{~cm}$ higher compared to students in the second group.

The health benefits of daylight have also been demonstrated in healthcare facilities. Benedetti et al. (2001) investigated the effect of direct sunlight in the morning on the length of hospitalization of depressed bipolar patients. The length of hospitalization was recorded for a sample of 415 unipolar and 187 depressed bipolar patients, assigned to rooms with eastern or western windows. Bipolar patients exposed to direct sunlight in the morning had on average 3.67-day shorter hospital stays than patients in western rooms. No effect was found in unipolar patients. A similar study was performed by Beauchemin and Hays (1996). Patients in sunny rooms had on average 2.6-day (15\%) shorter stays compared to those in dull rooms. Heerwagen (1986) found that patients with a view of trees had better post-surgical recovery, while patients in the same hospital with a view of a brick wall stayed longer, took more narcotic analgesics, and had more post-surgical complications. Choi et al. (2012) studied the effect of daylight on patients' average length of hospital stay. They compared different orientations of patient rooms in each ward of the general hospital in Incheon, Korea. The results showed 16-41\% shorter hospital stay in wards with optimal daylight conditions. Daylight also has an important role in curative and preventive medicine. Terman et al. (1986) claimed that improved interior lighting could reduce the common subclinical problems, such as oversleeping, overeating, energy loss, and work disturbance. Light can help cure rickets, osteomalacia, and Seasonal Affective Disorder (SAD).

Lack of daylight in built environments has adverse health effects on human health and their determinants. Daylight has been associated with improved mood and enhanced morale (Robbins 1986). Clark and Watson (1988) found that negative moods are associated with discomfort and distraction, whereas positive moods are associated with the physical setting at work and daily activities, such as social interactions among employees, which often results in lower absenteeism rates. Markussen and Røed (2014) examined the impact of hours of daylight on sick-leave absences among workers in Norway. They found that each additional hour of daylight increases the daily entry rate to absenteeism by $0.5 \%$ and the corresponding recovery rate by $0.8 \%$. The overall relationship between absenteeism and daylight hours was negative.

Nicklas and Bailey (1997) investigated the relationships between elementary and middle school student performance in North Carolina and natural daylighting. The results showed that the students who attended daylit schools outperformed those attending non-daylit schools by $5-14 \%$. Moreover, children under electric lights 
throughout the day showed decreased mental capabilities, agitated physical behaviour, and fatigue (Hathaway et al. 1992). Abdel-Hamid et al. (2013) carried out a cross-sectional study at the Faculty of Medicine, Ain Shams University, Cairo, Egypt. The results of the self-administered questionnaire with 826 workers showed that fatigue and headache were the most prevalent symptoms related to SBS (76.9 and $74.7 \%$ ). Poor lighting, lack of sunlight and absence of air currents were associated statistically with SBS symptoms and were affected also by other parameters: poor ventilation, high noise, temperature, humidity, environmental tobacco smoke, use of photocopiers, and inadequate office cleaning.

In the framework of a WHO workshop on Electromagnetic Hypersensitivity it was described as: "sensitivity to electromagnetic field (EMF) that comprises nervous system symptoms like headache, fatigue, stress, sleep disturbances, skin symptoms like prickling, burning sensations and rashes, pain and ache in muscles and many other health problems" (WHO 2004, p. V).

Related to adverse health effects due to exposure to electromagnetic fields $(\mathrm{EMF})$, many articles have been published over the years. A recent in-depth review of the scientific literature, WHO (2014), concluded that current evidence did not confirm the existence of any health consequences from exposure to low-level EMF. Exposures to higher levels that might be harmful are restricted by national and international guidelines. However, a number of epidemiological studies (WHO 2014) suggest small increases in risk of childhood leukaemia with exposure to low-frequency magnetic fields at home. Some individuals reported "hypersensitivity" to electric or magnetic fields. Eriksson and Stenberg (2006) investigated the prevalence of general, mucosal, and skin symptoms in the Swedish population ( $\mathrm{N}=3,000$, age 18-64). The survey addressed 25 symptoms, principally general, mucosal, and skin symptoms. The SBS symptoms, skin symptoms and symptoms similar to those reported by individuals with "electric hypersensitivity" were significantly more prevalent among employees who used display screen equipment extensively.

Small air ions are electrically charged clusters consisting of atmospheric molecules or atoms that have lost or gained electrons to impart a net positive or negative charge. Atmospheric space charge in the form of small air ions may be generated from natural sources, such as changes in atmospheric and weather conditions, including rain, wind, and snow, as well as natural radioactivity in geological formations, cosmic radiation, waterfalls, and combustion processes (Alexander et al. 2013). 
Researchers (ILO 2011; Reilly and Stevenson 1993) support the view that negative ions have a positive effect on health, including improved mood, stabilized catecholamine regulation and circadian rhythm, enhanced recovery from physical exertion and protection from positive ion-related stress and exhaustion disorders. The minimum acceptable concentration of negative ions for indoor air is 200-300 ions per $\mathrm{cm}^{3}$. The optimal level is 1000-1500 negative ions per $\mathrm{cm}^{3}$ (Jokl 1989). The lack of negative ions in the air may be responsible for SBS (ECA 1989). Bowers et al. (2018) evaluated the effectiveness of 30- and 60-minute daily exposure to high-density compared to zero-density (placebo condition) negative air ions over 18 days on the symptoms of seasonal affective disorder (SAD) in 40 participants under controlled laboratory conditions. The results showed that exposure to negative air ions significantly improved winter depression symptoms. All sources of fire (Sulman 1980a, b), and especially cigarette smoking (Jokl 1989), electrical radiators, and air-conditioners increase the concentration of positive ions, which may be related to SBS. According to Sulman (1980a, b), the reported physiological effects of positive ions include inhibited cell tissue culture growth, increased respiratory rate, increased basal metabolism, increased blood pressure, headache, fatigue, nausea, nasal obstructions, sore throat, dizziness and increased skin temperatures. The researchers found that the electrical charges (positive ionization) engendered by approaching weather fronts produce the release of serotonin and weather sensitivity reactions (irritation syndrome, exhaustion syndrome, hyperthyroidism) (Sulman 1980a, b). One way to increase the level of negative ions in indoor environments is a water fountain or live plants (which must be non-toxic). Plants can also be used for phytoremediation, the removal of toxins from the air to ameliorate indoor air quality. The ability of species to remove benzene, formaldehyde, and other indoor air pollutants has been proven by studies (Liu et al. 2007; Aydogan and Montoya 2011).

Ergonomics is the science of matching the job to the worker and the product to the user (Pheasant 1991, p. 3). The main approach of ergonomics is in user-centred design: "If a product (environment or system) is intended for human use, then its design should be based on the characteristics of its human users" (Pheasant 1986, 1987).

Principles of user-centred design are combined in universal design.

Universal Design is a design and composition of an environment, which can be accessed, understood and used to the greatest extent possible by all people regardless of their age, size, ability or disability. An environment (or any building, product or service in that environment) should be designed to meet the needs of all people who use it. This is not a special requirement from 
which only a minority of the population benefits, but a fundamental condition of good design (NDA 2014).

Hedge and Erickson (1998) define that worker ergonomics (designing the work/ environment/process/equipment to fit the worker, instead of forcing the worker to fit the work/environment/process/equipment) and issues of universal design (barrier-free environment for all groups of functional disabilities) (Dovjak and Kristl 2009) also involves significant physical risk factors that have to be considered for the prevention of SBS.

\subsection{Association Between Potential Health Outcomes and Chemical Health Risk Factors in Built Environments}

The most important chemical risk factors affecting health are construction and household products and emitted pollutants from furniture and equipment, especially formaldehyde, phthalates, volatile organic compounds, odours, environmental tobacco smoke, biocides, and others. According Simmons and Richard (1997), many construction products used for waterproofing, insulating, fireproofing, roofing, painting, plastering, building and treating floors, as well as surface coatings, contain toxic chemicals.

The first epidemiological studies of cancer risk in relation to exposure to asbestos were reported in the 1950s (Marsili et al. 2016). Until the late 1970s, asbestos was used in construction products such as asbestos insulation, roofing, flooring, adhesives, duct connectors as well as protective clothing, household items, and others. All types of asbestos cause lung cancer, mesothelioma, cancer of the larynx and ovary, and asbestosis (fibrosis of the lungs) (WHO 2017c). According to Commission Directive (1999), all EU Member States banned asbestos in 2005. Consequently, for countries that have stopped using asbestos, their asbestos-related disease burden will most likely decrease (Kameda et al. 2014). Nevertheless, the EU currently carries the largest share of the global asbestos-related disease burden as a consequence of heavy asbestos use in previous decades.

European countries that adopt the EU REACH regulation restrict the use and sale of certain specific lead compounds for use in paints (UNEP 2016). Nevertheless, in many countries, architectural/decorative paints still contain significant concentrations of lead (Gottesfeld 2015). Childhood lead poisoning has been a recognized clinical entity since the first decade of the 20th century, when leaded petrol and lead-based paints were common (WHO 2010).

Many new chemicals have not yet been tested for their impact on human health, which presents a problem (Petrović 2017). The problem of exponential increase in 
the development of synthetic and petroleum-based chemicals since World War II was highlighted by Petrović (2017). The problem is even more serious in case of numerous emission sources, such as radon emission from constructional complexes (i.e., fly ash bricks) and from soils and rock (Chauhan et al. 2003). The exposure of people to high concentrations of radon and its isotopes for an extended period leads to pathological effects, such as functional respiratory changes and the occurrence of lung cancer (EPA 2017a).

Throughout their life cycle construction products may emit harmful substances in the surrounding environment (Šestan et al. 2013; Dovjak and Kristl 2011). To provide good indoor air quality (IAQ), holistic measures with step-by-step activities have to be performed (i.e., including actions on location-building/constructional complexes-system). At the first stage of design, it is important to perform source control measures with the selection of non-toxic construction products. Moreover, some researchers have also studied so-called sorptive building material as an effective method for improving IAQ. Park et al. (2015) proved the effect of concentration reduction through the use of sorptive building materials in office areas.

In addition to construction products, household products also have to be considered from the aspects of IAQ. For example, the use of air-fresheners may be related to poor indoor air quality and may lead to SBS symptoms and other adverse health effects (NIPH 2009; Zock et al. 2007; Cohen et al. 2007). Within the follow-up of the European Community Respiratory Health Survey in 10 countries, Zock et al. (2007) identified 3,503 persons without asthma, who were regularly cleaning their homes. The results showed that the use of cleaning sprays at least once a week (42\% of participants) was associated with the incidence of asthma symptoms or medication and wheeze. The incidence of physician-diagnosed asthma was higher among those who used sprays at least 4 days per week. Dose-response relationships were apparent for the frequency of use and the number of different sprays.

Moreover, due to low air humidity in buildings, humidifiers are often used. Humidifiers in the ventilation circuit provide a source of microbes to flourish, and also provide a reason for adding biocides to humidified water. Many of these biocides are irritants or allergens (Burge 2004). These products are highly irritant in concentrated form; when dispersed in the indoor atmosphere, at low concentrations, they may cause mucous membrane irritation in susceptible individuals (Burge 2004).

Construction products and wooden furniture (e.g., plywood, particleboard, fibreboard, OSB, panel boards, urea-formaldehyde foam), paints, adhesives, varnishes, floor finishes, disinfectants, cleaning agents and other household products emit formaldehyde (HCHO) (Šestan et al. 2013).

The results of several studies of indoor/outdoor ratios of formaldehyde in buildings range approximately from 3 to 18 (ARB 2012; Blondel and Plaisance 
2011; Sakai et al. 2004). Formaldehyde may be the cause of SBS, because it irritates both the eyes, as well as the upper and lower respiratory tract. It may also be responsible for allergic disorders, including asthma (Hendrick and Lane 1977). In a study among students in schools in Malaysia ( $\mathrm{N}=462$ pupils), formaldehyde and other selected indoor air pollutants were associated with rhinitis, ocular, nasal and dermal symptoms, headache, and fatigue. Norbäck et al. (2017) arrived at similar findings. Formaldehyde was associated with ocular $(\mathrm{p}=0.004)$, throat symptoms $(\mathrm{p}=0.006)$ and fatigue $(\mathrm{p}=0.001)$.

Šestan et al. (2013) reviewed 11 epidemiological studies that monitored the concentrations of formaldehyde in buildings (nine studies on residential buildings and two studies on public buildings). They found that the measured concentrations of formaldehyde ranged from $0.0016 \mathrm{ppm}\left(2 \mu \mathrm{g} / \mathrm{m}^{3}\right)$ to $0.109 \mathrm{ppm}\left(134 \mu \mathrm{g} / \mathrm{m}^{3}\right)$. The measured concentrations from the reviewed studies may cause irritation of the upper respiratory tract in the exposed individuals. An examination of studies (2005 and more recent studies) (Salthammer et al. 2010) indicated that under normal living conditions the average exposure to formaldehyde seems to lie between $0.0163 \mathrm{ppm}\left(20 \mu \mathrm{g} / \mathrm{m}^{3}\right)$ and $0.0326 \mathrm{ppm}\left(40 \mu \mathrm{g} / \mathrm{m}^{3}\right)$. Salthammer et al. (2010) also emphasized that new buildings with changed microclimate conditions may exhibit higher average and maximum concentrations, which may lead to the increased exposures and health risks, particularly in the group of sensitive individuals.

Polyvinyl chloride (PVC) construction products usually contain plasticisers, phthalate esters that may be emitted from PVC during the whole life cycle of the product. PVC materials are problematic during normal use of the building or during emergency situations (i.e., fire).

A comprehensive literature review by Dovjak and Kristl (2011) indicated that the use of PVC construction products in indoor environments may have adverse health effects. Phthalates are thought to be responsible for low testosterone levels, declining sperm counts and quality, genital malformations, retarded sexual development or even reproductive abnormalities and increased incidences of certain types of cancer (Heudorf et al. 2007). Epidemiological studies (Jaakkola et al. 1999; Bornehag et al. 2004) state that the presence of PVC flooring and walls is related to asthma, rhinitis, wheeze, cough, phlegm, nasal congestion, nasal excretion and eczema in children. These findings underscore the need to consider the health aspects of materials used in indoor environments.

A systematic review and meta-analysis of 14 laboratory toxicology studies in adults (1950-2007) assessed the relationship between PVC-related occupational exposure (meat wrappers, hospital and office workers, firefighters, PVC processors) and the risk of asthma, allergies, or related respiratory effects (Jaakkola and Knight 2008).

In the study by Subedi et al. (2017), the concentrations of potentially toxic plasticizers (phthalates and non-phthalates) were investigated in 28 dust samples 
collected from three different indoor environments (e.g., homes, salons, and day-care centres) across the USA. The estimated daily intakes of total phthalates $(n=7)$ for children and toddlers through indoor dust in childcare facilities were 1.6 times higher than the non-phthalate plasticizers $(n=3)$, whereas the estimated daily intake of total non-phthalates for all age groups in the domestic environment was 1.9 times higher than the phthalate plasticizers. This study reveals a more elevated ( $\sim 3$ fold) occupational intake of phthalate and non-phthalate plasticizers through the indoor dust at hair salons compared to domestic environments in the USA.

During emergency situations (e.g., in case of fire), hazardous products such as carbon monoxide, carbon dioxide, hydrogen chloride, hydrochloric acid, dioxins, smoke/soot, etc. may form (Dovjak and Kristl 2011).

Phthalates can be adsorbed onto indoor surfaces (carpet, wood, and skin) and re-emitted in the indoor air (Xu et al. 2009).

Man-made mineral fibre (MMMF) is a generic name used to describe an inorganic fibrous material manufactured primarily from glass, rock, minerals, slag and processed inorganic oxides. According to the International Agency for Research on Cancer (IARC 2002), MMMF is classified into five categories: continuous glass filament, glass wool (insulation wool and special purpose wool), rock wool, slag wool, refractory ceramic and other.

According to the results of epidemiological studies, MMMFs have adverse health effects (EC 2012). Acoustic ceilings may contain MMMF that may be transferred from such surfaces to skin and eyes, normally by direct hand contact. However, MMMF may also be transferred via air transmission modes. Nielsen (1987) proved that especially high concentrations may be found in rooms with uncovered ceilings, but also in rooms where the fibres are bound by a water-soluble glue and exposed to water damage. Unsealed fibreglass and other insulation material lining the ventilation ducts can release particulate material into the air. Such material can also become wet, creating an ideal and often concealed growth medium for microorganisms (Redlich et al. 1997).

Volatile organic compounds (VOCs) are emitted as gases from certain solids or liquids. VOCs include a variety of chemicals, some of which may have short and long-term adverse health effects. Sources of VOCs are household products (e.g., wood preservatives, aerosol sprays, cleansers and disinfectants, moth repellents and air fresheners, stored fuels and automotive products, hobby supplies, dry-cleaned clothing, pesticide) and other products (building materials and furnishings, office equipment) (EPA 2017b). 
Volatile organic compounds (VOCs) are suspected to be one of the major causes of SBS (Nakaoka et al. 2014; Yu and Kim 2012; Logue et al. 2011; Takigawa et al. 2009; Wang et al. 2007; Mølhave 2003; Schneider et al. 2003; Hodgson 2002; Wolkoff 1987). Construction products, furniture, household products (waxes, detergent, insecticides), products of personal hygiene (cosmetics), do-it-yourself goods (resins), office materials (photocopier ink) or environmental tobacco smoke (ETS) are all sources of VOCs in indoor environments. Wolkoff (1987) found that concentrations of VOCs depend on the type of the room, activity and time. VOCs may affect human health and can sometimes also be the source of odours (ECA 1989). Takigawa et al. (2009) conducted a study in residential buildings in Okayama, Japan ( $\mathrm{N}=86$ men, 84 women). The results showed that aldehyde levels in indoor air increased frequently and markedly in the newly diseased and ongoing SBS groups. About 10\% of subjects suffered from SBS in 2004 and 2005. Similar findings were made by Takigawa et al. (2012). They studied 871 people living in 260 single-family houses in 2004 and 2005. Approximately 14 and $12 \%$ of subjects were identified as having SBS in the first and second years, respectively. Elevated levels of indoor aldehydes and aliphatic hydrocarbons in indoor air increased the possible risk of SBS to occur in residents living in new houses. Goodman et al. (2017) systematically evaluated 25 years (1991-2016) of investigations of VOC presence in Australian indoor environments. New homes had the highest VOC levels among all studies of domestic housing. Concentrations of nearly all pollutants were several times higher indoor compared to outdoor. Terpenes (d-limonene and $\boldsymbol{\alpha}$-pinene) were among the most indoor prevalent compounds.

Odours are organic or inorganic compounds that originate from within a building, or they can be drawn into a building from the outdoors. Indoor odour sources are usually associated with construction products, household products, furnishings, office equipment, insufficient ventilation, problems with mould, bio-effluents, etc. Odours are a significant source of indoor environmental quality problems in buildings (CDC 2013).

According to the Report of the European Commission on SBS ECA (1989), the hidden olfs (a unit used to measure the strength of a pollution source) from materials and systems are claimed to be one of the major reasons for SBS. Nakaoka et al. (2014) examined the correlation between the sum of VOCs, total odour threshold ratio, and SBS symptoms. The findings indicated that the total odour threshold ratio and the concentration of VOCs were correlated with SBS symptoms among sensitive people. Wang et al. (2013) studied the prevalence of perceptions of odours and sensations of air humidity and SBS symptoms in domestic environments. Parents $(\mathrm{N}=4,530)$ of 1-to-8-year-old children from randomly selected kindergartens in Chongqing, China participated. Stuffy odours, unpleasant odour, pungent odour, mould odour, tobacco smoke odour, humid air and dry air in 
the preceding three months (weekly or sometimes) was reported by $31.4 \%, 26.5 \%$, $16.1 \%, 10.6 \%, 33.0 \%, 32.1 \%$ and $37.2 \%$ of the parents, respectively. The prevalence of parents regarding SBS symptoms was: $78.7 \%$ for general symptoms, $74.3 \%$ for mucosal symptoms, and $47.5 \%$ for skin symptoms. Multi-nominal regression analyses for associations between odours/sensations of air humidity and SBS symptoms showed that the odds ratio for "weekly" SBS symptoms was consistently higher than for "sometimes" SBS symptoms.

Environmental tobacco smoke (ETS) is composed of both mainstream and side-stream smoke. ETS usually contains more than 4,000 different chemicals. Undiluted side-stream smoke contains higher concentrations of several chemicals than the mainstream smoke inhaled by the smoker. These chemicals include 2-naphthylamine, N-nitrosodimethylamine, 4-aminobiphenyl, and carbon monoxide (CCOHS 2011). The side-stream smoke may even be more of an irritant than the mainstream smoke (ECA 1989).

ETS is one of the main causes of SBS symptoms (CCOHS 2011). Studies on the correlations between ETS exposure and SBS showed that SBS was statistically more pronounced in smokers than in non-smokers (Valbjorn and Skov 1987) and there was an increase of symptoms in non-smokers and ex-smokers exposed to ETS in comparison to the same non-exposed categories (Robertson et al. 1988). Mizoue et al. (2001) analysed the data from a 1998 cross-sectional survey of 1,281 municipal employees who worked in a variety of buildings in a Japanese city. Among non-smokers, the odds ratio for the association between SBS and $4 \mathrm{~h}$ of ETS exposure per day was 2.7, and for most symptom categories, the odds ratios increased with increasing hours of ETS exposure. Working overtime (for 30 or more hours per month) was also associated with SBS symptoms, but the crude odds ratio of 3.0 for SBS was reduced by $21 \%$ after adjustment of variables associated with overtime work and by $49 \%$ after further adjustment of perceived work overload.

$\mathbf{C O}_{2}$ is one of the most important indicators for indoor air quality and adequacy of building ventilation. The main indoor source of $\mathrm{CO}_{2}$ in most buildings is human metabolic activity.

In terms of worker safety, Occupational Safety and Health Administration (OSHA) set a permissible exposure limit (PEL) for $\mathrm{CO}_{2}$ of 5,000 parts per million (ppm) over an eight-hour workday. Similarly, the American Conference of Governmental Industrial Hygienists (ACGIH) defined the TLV (threshold limit value) as 5,000 ppm for an eight-hour workday, with a ceiling exposure limit of 30,000 ppm for a 10-minute period based on acute inhalation data (NIOSH 1976). 
For the design and assessment of energy performance in buildings, recommended $\mathrm{CO}_{2}$ concentrations above outdoor concentration are defined by EN 1525 (2007). For example, for a Category I environment, the recommended $\mathrm{CO}_{2}$ concentration for energy calculations and required control is $350 \mathrm{ppm}$ above outdoors. ANSI/ ASHRAE Standard 62.1 (2004) defines that $\mathrm{CO}_{2}$ concentration should not exceed $2500 \mathrm{ppm}$, while $1000 \mathrm{ppm}$ is the recommended value.

According to national Rules on the ventilation and air-conditioning of buildings (OJ RS No. 42/2002, 105/2002), the permissible value of $\mathrm{CO}_{2}$ in indoor air is $3000 \mathrm{mg} / \mathrm{m}^{3}$ (1667 ppm). However, studies report that even lower levels of $\mathrm{CO}_{2}$ concentrations, compared to these recommended or regulated concentrations, may lead to occupant dissatisfaction and decreased productivity (Bakó-Biró et al. 2007). For example, concentrations higher than $1000 \mathrm{ppm}$ were associated with an increased percentage of dissatisfied occupants (ECA 1989). Especially high concentrations were detected in 24 school buildings in Slovenia (Butala and Novak 1999), where the maximal concentration of $\mathrm{CO}_{2}$ was above $7198 \mathrm{mg} / \mathrm{m}^{3}$ (4000 ppm).

Seppänen et al. (1999) reviewed 41 studies with over 60,000 subjects on the associations between ventilation rates and $\mathrm{CO}_{2}$ concentrations in non-residential and non-industrial buildings (primarily offices) with health outcomes. The risk of the SBS symptoms continued to decrease significantly with decreasing $\mathrm{CO}_{2}$ concentrations below $800 \mathrm{ppm}$. A similar conclusion was presented in the study by Erdmann et al. (2002), Apte et al. (2000) and Tsai et al. (2012). Erdmann et al. (2002) found that higher concentrations of $\mathrm{CO}_{2}$ (workday time-averaged indoor minus outdoor $\mathrm{CO}_{2}$ concentrations) were associated with an increased prevalence of certain mucous membrane and lower respiratory SBS symptoms. Even the highest $\mathrm{CO}_{2}$ concentrations did not exceed $1000 \mathrm{ppm}$. Apte et al. (2000) evaluated the relationship between indoor $\mathrm{CO}_{2}$ concentrations and the SBS symptoms in occupants from 41 U.S. office buildings. Results showed that dose-response relationship with odds ratios per $100 \mathrm{ppm} \mathrm{CO}_{2}$ ranged from 1.2 to 1.5 for sore throat, nose/ sinus, tight chest, and wheezing. Tsai et al. (2012) evaluated the SBS symptoms among 111 office workers in August and November 2003. The most common symptoms of the five SBS groups were eye irritation, nonspecific and upper respiratory symptoms. They also proved that workers exposed to indoor $\mathrm{CO}_{2}$ levels greater than $800 \mathrm{ppm}$ were likely to report eye irritation or upper respiratory symptoms more frequently.

From the public health perspective, an important association was found between different sources of exposure to indoor air and health effects. The systematic review included eight studies that found associations between asthma and high levels of PM, VOC and endotoxins (Erklavec et al. 2017). Norbäck et al. (2017) studied associations between VOC, formaldehyde, nitrogen dioxide $\left(\mathbf{N O}_{2}\right)$ and $\mathrm{CO}_{2}$ in schools in Malaysia ( $\mathrm{N}=462$ pupils) and rhinitis, ocular, nasal and dermal symptoms, headache and fatigue among students. The prevalences of weekly rhinitis, ocular, throat and dermal symptoms were $18.8 \%, 11.6 \%, 15.6 \%$, and $11.1 \%$, respectively. In total, $20.6 \%$ of students had weekly headaches and $22.1 \%$ fatigue. $\mathrm{NO}_{2}$ was associated with ocular symptoms $(\mathrm{p}<0.001)$ and fatigue 
$(p=0.01)$. Formaldehyde was associated with ocular $(p=0.004)$, throat symptoms $(\mathrm{p}=0.006)$ and fatigue $(\mathrm{p}=0.001)$. Xylene was associated with fatigue $(\mathrm{p}<0.001)$, and benzaldehyde was associated with headache $(\mathrm{p}=0.03)$. In conclusion, xylene, benzaldehyde, formaldehyde and $\mathrm{NO}_{2}$ in schools can be risk factors for fatigue, ocular, and throat symptoms among students in Malaysia.

\subsection{Association Between Potential Health Outcomes and Biological Health Risk Factors in Built Environments}

Microorganisms are always present in our living space, but higher concentrations are a risk factor for the onset of various diseases, as they can affect people's well-being, work performance, and productivity, and trigger a number of negative effects on health. Microorganisms can have direct or indirect effects on the quality of our living space, health, and well-being. Building operation, ventilation, and occupancy drive the building microbiology. Buildings represent a good media for the growth of microorganisms (Adams et al. 2016).

Biological contaminants present in indoor air include bacteria, moulds, mildew, viruses, animal dander and cat saliva, house dust, mites, cockroaches, and pollen (EPA 2012). There are many indoor or outdoor sources of these pollutants (e.g., people, animals, soil, plant debris). Microbial pollution involves hundreds of species of bacteria and fungi that grow indoors when sufficient moisture is available. Exposure to microbial contaminants is associated with respiratory symptoms, allergies, asthma, and immunological reactions (WHO 2009c).

Mould is all species of microscopic fungi that grow in the form of multicellular filaments, called hyphae. In contrast, microscopic fungi that grow as single cells are called yeasts. A connected network of tubular branching hyphae has multiple, genetically identical nuclei and is considered a single organism, referred to as a colony (Madigan and Martinko 2005).

The study by Straus (2009) emphasized the importance of moulds and their mycotoxins in the phenomenon of SBS. Zhang et al. (2012) studied the associations between dampness and indoor moulds in workplace buildings and selected biomarkers as well as incidence and remission of SBS. The study was based on a ten-year prospective study (1992-2002) in a random sample of adults $(\mathrm{N}=429)$ from the Uppsala part of the European Community Respiratory Health Survey. Dampness was associated with increased incidence and decreased remission of SBS. Dampness and moulds increased bronchial responsiveness and eosinophilic inflammation. A similar study was performed by Sahlberg et al. (2013) in 159 homes of inhabitants in three EU cities (Reykjavik, Uppsala, Tartu). The 
associations between SBS, microbial volatile organic compounds (MVOC), and reports on dampness and mould were examined. The results showed that the indoor levels of some MVOCs were positively associated with SBS. Levels of airborne moulds and bacteria and some MVOCs were higher in dwellings with a history of dampness and moulds. Problems with dampness also exist in other environments, such as dorm rooms and schools. Sun et al. (2013) carried out a study in 1,569 dorm rooms in Tianjin, China (2006-2007; $\mathrm{N}=3,712$ students). A "mouldy odour" or "dry air" were perceived by occupants in $31 \%$ of dorm rooms. The adjusted odds ratio (AOR) of perceived mouldy odour for general SBS symptoms was 2.4, for mucosal symptoms 2.2, and for skin symptoms 2.0. Local mouldy odour around room corners or under radiators was reported by inspectors in $26 \%$ of dorm rooms. The study concluded that local mouldy odour perceived by inspectors was a significant risk factor for nose irritation (AOR 2.8).

\section{BOX 3.8 Adjusted odds ratio (AOR)}

Adjusted odds ratios (AOR) are most commonly used when the analysis includes several variables and takes into account the effect of all variables. Stratification and multiple regression techniques are two methods used to address confounding and produce "adjusted" ORs (Szumilas 2010).

Zhang et al. (2011) analysed the relationship between the concentration of allergens and microbial compounds and new onsets of SBS. The study was based on a two-year prospective analysis of pupils $(\mathrm{N}=1,143)$ in a random sample of schools in China. The prevalence of mucosal and general symptoms was $33 \%$ and $28 \%$, respectively, at baseline, and it increased during follow-up. At baseline, $27 \%$ reported at least one symptom that improved when pupils were away from school (school-related symptoms). The authors concluded that exposure to mould could increase the incidence of school-related symptoms.

Moulds as a consequent phenomenon of flooding were considered by a few studies. The review by Crook and Burton (2010) describes the role of moulds in SBS and BRI as a clinical condition with defined symptoms and signs in which the cause (aetiology) is building related and identifiable. In their study, they use as examples the after-effects of flooding in the UK in 2007, and Hurricane Katrina in the USA in 2005. These studies reported the health effects of exposure to moulds. Respiratory symptoms were positively correlated with exposure to water-damaged homes. Studies also concluded that respirators reduced symptoms when worn while in the water-damaged homes. The most commonly reported symptoms were nasal symptoms and cough. 
Bacteria are defined as microscopic, single-celled organisms belonging to the Kingdom Monera that possess a prokaryotic type of cell structure, which means their cells are non-compartmentalized, and their DNA (usually circular) can be found throughout the cytoplasm rather than within a membrane-bound nucleus. Bacteria reproduce by fission or by forming spores. They can practically live everywhere. They can inhabit all kinds of environment, such as in soil, acidic hot springs, radioactive waste, seawater, deep in the Earth's crust, in the stratosphere, and even in the bodies of other organisms (Biology online 2017).

Teeuw et al. (1994) carried out a survey of SBS among 1,355 employees working in 19 governmental office buildings in the Netherlands. Physical, chemical, and microbiological characteristics between mechanically ventilated and naturally ventilated buildings were examined. Mechanically ventilated buildings were grouped as "healthy" or "sick" based on symptom prevalence (mean symptom prevalence $<15 \%$ or $>15$ or $=15 \%$ ). The authors found no differences in physical characteristics. However, the concentration of airborne endotoxin and Gram-negative rods were found in higher numbers in the "sick" mechanically ventilated buildings than in the "healthy" mechanically ventilated buildings and naturally ventilated buildings. The study concluded that airborne microbial contamination, in particular with Gram-negative rods and perhaps with endotoxin, may have a role in the causation of SBS.

Al-Hunaiti et al. (2017) analysed the floor dust bacteria and fungi and their coexistence with PAHs in Jordanian indoor environments (eight dwellings and an educational building) in Amman. The results showed that bacterial and fungal concentrations varied significantly among and within the tested indoor environments. Educational buildings have higher Gram-negative bacteria concentration than dwellings. Gram -/+ bacteria and total fungal concentrations were positively correlated.

Microbes volatile organic compounds (MVOCs) are a variety of volatile organic compounds formed in the primary and secondary metabolism of microorganisms (Korpi et al. 2009; Fu 2016). They are associated with mould and bacterial growth and responsible for the odorous smells (Ammann 1988). In total, around 1,200 MVOC have been identified, and around $250 \mathrm{MVOC}$ from mould have been measured in indoor environmental studies (Fu 2016). The most obvious health effect of MVOC exposure is eye and upper-airway irritation (Korpi et al. 2009).

Araki et al. (2010) measured indoor MVOC levels in single-family homes and evaluated the relationship between exposure to them and SBS. The most frequently 
detected MVOC was 1-pentanol. Among 620 participants, 19.4\% reported one or more mucous symptoms; irritation of the eyes, nose, airway, or coughing every week (weekly symptoms), and $4.8 \%$ reported that the symptoms were home-related. Weekly symptoms were not associated with any MVOC, whereas significant associations between home-related mucous symptoms and 1-octen-3-ol and 2-pentanol were obtained. Additionally, Sahlberg et al. (2013) examined whether MVOCs and airborne levels of bacteria, moulds, formaldehyde, and two plasticizers in dwellings were associated with the prevalence of SBS and studied associations between MVOCs and reports on dampness and mould. A total of 159 adults (57\% females) participated (19\% from Reykjavik, $40 \%$ from Uppsala, and 41\% from Tartu). The results showed that MVOCs, such as 1-octen-3-ol, formaldehyde and the plasticizer Texanol, may be a risk factor for sick building syndrome. Moreover, concentrations of airborne moulds, bacteria and some other MVOCs were slightly higher in homes with reported dampness and mould. Some MVOCs may have adverse effects on respiratory, nervous, and circulatory systems and may have carcinogenic effects (Yu et al. 2009).

A case-control investigation by Choi et al. (2017) studies the association between MVOC and its risks on childhood asthma and allergies within damp homes (198 cases, 202 controls). Results showed that among the children who lived in high absolute humidity homes, a natural $\log (\ln )$-unit of total sum of 28 MVOCs was associated with 2.5-times greater odds of the case status (95\% CI, 1.0-6.2; $\mathrm{p}=0.046)$, compared to 0.7-times the odds $(95 \% \mathrm{CI}, 0.4-1.0 ; \mathrm{p}=0.074)$ of the same outcome among low absolute humidity homes. Specifically, joint exposure to high MVOCs and high absolute humidity was associated with 2.6-times greater odds of the doctor-diagnosed asthma status (95\% CI, 0.7-8.91; $\mathrm{p}=0.137$ ).

\section{BOX 3.9 Confidence interval (CI)}

Confidence interval (CI) is a type of interval estimate (of a population parameter) that is computed from the observed data. It gives an estimated range of values which is likely to include an unknown population parameter, the estimated range being calculated from a given set of sample data (Easton and McColl 1997).

Pantoja et al. (2016) analysed the air quality of a public referral hospital in Fortaleza, Ceará, Brazil in terms of fungal volatile organic compounds (FVOCs), to establish ways to improve monitoring methods and control of specific sectors in the hospital. The results showed that 2-heptanone and 2-methyl-1-propanol were the most frequent FVOCs. Moreover, the climatic data showed the incidence of FVOCs regardless of the climatic season. 
Dust in homes, offices, and other built environments contains various organic and inorganic matter (Hess-Kosa 2002). The quantity and composition of house dust vary greatly with seasonal and environmental factors and also depends upon the HVAC system, cleaning habits, occupant activities, etc.

Poor building service maintenance, poor cleaning or poor cleanability increases the prevalence of SBS (Burge et al. 1990). Nexo et al. (1983) demonstrated a correlation between the organic dust content of carpets (predominantly skin scales, bacteria, and moulds) and the symptoms of SBS. Among 12 employees, five had symptoms related to the workplace.

Dust often contains substances emitted from construction products (e.g., phthalate esters and other plasticisers emitted from PVC construction products). Many emitted substances may have significant health concerns. Kishi et al. (2012) performed a study in which dust samples were collected from the living rooms of 182 single family dwellings in six cities in Japan. The prevalence of SBS, asthma, atopic dermatitis, allergic rhinitis and conjunctivitis was $6.5 \%, 4.7 \%, 10.3 \%, 7.6 \%$ and $14.9 \%$, respectively. Significant associations between the medical treatment of asthma and floor bis (2-ethylhexyl) adipate (DEHA) and multi-surface di-n-butyl phthalate (DnBP), dermatitis and floor BBzP and DEHA, conjunctivitis and floor Bis(2-ethylhexyl) phthalate (DEHP) were obtained after adjustment.

Office buildings normally have very low concentrations of mites, because they do not provide appropriate conditions for their growth. Mites are, however, relatively abundant in household dust. They can be destroyed by keeping absolute humidity below $7 \mathrm{~g} / \mathrm{kg}$ of air (about 45\%) during the winter time (ECA 1989). Airborne house dust frequently causes allergic symptoms. However, house dust may also be problematic for healthy subjects without hypersensitivity reactions, as presented by Mølhave et al. (2000). This Danish Office Dust Experiment (Mølhave et al. 2000) investigated the response of 24 healthy non-sensitive adult subjects to the exposure to normal office dust in the air. The responses were both subjective sensory reactions and other neurogenic effects even at exposure levels within the range found in normal buildings. Some of the effects appeared acutely and decreased through adaptation, while others increased during prolonged exposure and remained for more than $17 \mathrm{~h}$ after the exposure had ended. The threshold level for the dose-response relationships was below $140 \mu \mathrm{g} / \mathrm{m}^{3}$.

\section{BOX 3.10 Dose-response relationship}

The dose-response relationship, or exposure-response relationship, describes the change in effect on an organism caused by differing levels of exposure (or doses) to a stressor (usually chemical) after a certain exposure time, or to a food (Crump et al. 1976). 


\subsection{Association Between Potential Health Outcomes and Psychosocial Health Risk Factors in Built Environments}

The category of psychosocial, personal and other risk factors for SBS includes gender, individual characteristics, health condition, stress, feelings of loneliness and helplessness, working position, social status, and others.

Gender, working position, and health characteristics are important health determinants. They cannot be controlled by individuals (WHO 2017a) but have to be carefully considered in the design process.

Stenberg et al. (1994) made a screening questionnaire study of 4,943 office workers and a case-referent study of SBS in 464 subjects. In the study, females reported SBS more often than males did. The same conclusions were found in the studies by Sun et al. (2013) in a dormitory environment in Tianjin, China (20062007) and in a study by Engvall et al. (2000) in multi-family buildings in Stockholm. Additionally, the influence and importance of gender on the prevalence of the SBS symptoms were investigated on 590 employees of three office buildings in Norway (Lenvik 1993). The results showed that a greater percentage of females than males reported having the SBS symptoms.

Women are often employed under less favourable working conditions than men, as was confirmed in the study by Bullinger et al. (1999). Questionnaire results from 2,517 female employees in Germany (as compared to 2,079 male employees) showed that women report higher scores in sensory irritation, a higher bodily complaint rate, and a more negative evaluation of the indoor climate. In addition, most psychosocial variables showed less favourable scores for women as compared to men.

The relative influence of gender, atopy, smoking habits, and age on reported SBS symptoms among office workers was investigated through questionnaire studies among 1,293 employees in 10 nonindustrial buildings (Lenvik 1993). The occurrence of atopy among the office workers was not found to be different from that of the general population. The prevalence of symptoms was higher among atopic individuals than among nonatopics and higher among females than among males. While gender was found to be important for some symptoms, atopy was important for all of them. The results indicated interrelations between smoking and atopy, with the enhanced prevalence of some symptoms. The age of the persons was also included in the analyses. Different ways of grouping age indicated different trends in associations between age and the prevalence of symptoms, but the study did not show any unambiguous associations between the age and the prevalence of symptoms. The same conclusion was made in the literature review by 
Norbäck (2009), showing that there was no consistent association between age and SBS.

Symptoms are generally more common and more problematic in the stressed, the unloved, and in individuals who feel powerless to change their situation. There is a strong association between lack of control of the office environment and symptoms and an association between lower social status and the SBS symptoms (Burge 2004). Norlen and Andersson (1993) showed that residents in single-family houses reported less SBS than those in multifamily houses, although measurements suggest a less favourable indoor environment in single-family houses.

Occupational stress has been shown to have a detrimental effect on the health and wellbeing of employees, as well as a negative impact on workplace productivity and profits (Bickford 2005).

Some researchers (Morris and Hawkins 1987; Hedge et al. 1987) have investigated the possible links between SBS symptoms and occupational stress. Occupational stress has been found to be correlated with SBS symptoms, but much of the research has been of a cross-sectional nature, and it does not indicate whether stress is an active element or an outcome (Crawford and Bolas 1996). However, Ooi and Goh (1997) examined the role of work-related psychosocial stress among 2160 subjects in 67 offices in the aetiology of SBS. Ooi and Goh (1997) found an incremental trend in the prevalence of SBS among office workers who reported high levels of physical and mental stress, and a decreasing climate of co-operation.

$\mathrm{Lu}$ et al. (2007) investigated whether SBS complaints and indoor air pollution for 389 office workers in 87 government offices of eight high-rise buildings in Taipei, Taiwan are associated with oxidative stress. Oxidative stress was indicated by urinary 8 -hydroxydeoxyguanosine $(8-\mathrm{OHdG})$. The results showed that urinary 8 -OHdG had significant associations with VOC and $\mathrm{CO}_{2}$ in offices, and with urinary cotinine levels. The mean urinary $8-\mathrm{OHdG}$ level was also significantly higher in participants with the SBS symptoms than in those without such complaints. The mean $8-\mathrm{OHdG}$ increased as the number of SBS symptoms increased. This study indicated that the $8-\mathrm{OHdG}$ level was closely associated with the SBS complaints after controlling the air pollution and smoking.

\subsection{Association Between Potential Health Outcomes and Other Factors in Built Environments}

In previous sections of this chapter, specific health risk factors in built environments were defined, presenting quite well-researched topics. However, in the first chapter, it was described that numerous health determinants impact built environments; many of them are poorly researched. Additionally, due to the specific characteristics 
of risk factors, some of the measurement techniques and analyses remain partly or even non-defined.

Other health risk factors in built environments for which health outcomes were proved by studies are: location, building characteristics, ownership, presence of insecticides, geopathogenic zones and geopathic stress, etc.

Wang et al. (2013) performed a study in domestic environments in Chongqing, China and confirmed that living near a main road or highway, redecoration, and new furniture were risk factors for perceptions of odours and sensations of humid air and dry air. The presence of cockroaches, rats, and mosquitoes/flies, use of mosquito-repellent incense and other incenses were all risk factors. The analyses of 609 multi-family buildings with 14,235 dwellings in Stockholm (Engvall et al. 2000) showed that subjects owning buildings reported less SBS, but the relationship between ownership and building age was strong. According to the model, $5 \%$ of all buildings built before 1961, $13 \%$ of those built in 1976-1984, and $15 \%$ of those built in 1985-1990 would have significantly more SBS than expected. Another issue that has to be investigated in relation to SBS is geopathogenic zones and geopathic stress.

\section{BOX 3.11 Geopathic stress}

The word "geopathic" is derived from two Greek words: geo, meaning "of the earth" and pathos, meaning "suffering" or "disease". Geopathic stress can undermine both the body's subtle energy system (the etheric body, chakras and meridians) and the body's electrical system (brain, heart and muscles), thus delaying healing and recovery. Interest in geopathic stress first arose in Germany in the 1920s (Freshwater 1997).

Augner et al. (2010) evaluated whether two different locations in the same room as tested by dowsers ("geopathic stress zone" versus "more neutral zone") would show significant short-term effects on work performance and well-being. The authors performed a blinded, randomized, short-term laboratory experiment $(\mathrm{N}=26$ persons, aged 20-57). Analysis of variance revealed a trend $(\mathrm{p}=0.07)$ and showed significantly poorer well-being under the geopathic stress zone condition compared to a more neutral zone $(\mathrm{p}=0.01)$. No location-dependent effects on performance during the reactive stress tolerance test were seen.

\section{References}

Abdel-Hamid, M. A., Hakim, S. A., Elokda, E. E., \& Mostafa, N. S. (2013). Prevalence and risk factors of sick building syndrome among office workers. The Journal of The Egyptian Public Health Association 88(2), 109-114. https://doi.org/10.1097/01.EPX.0000431629.28378.c0.

Adams, R. I., Bhangar, S., Dannemiller, K. C., Eisen, J. A., Fierer, N., Gilbert, J. A., et al. (2016). Ten questions concerning the microbiomes of buildings. Building and Environment 109, 224 234. https://doi.org/10.1016/j.buildenv.2016.09.001. 
Al-Hunaiti, A., Arar, S., Täubel, M., Wraith, D., Maragkidou, A., Hyvärinen, A., et al. (2017) Floor dust bacteria and fungi and their coexistence with PAHs in Jordanian indoor environments. Science of the Total Environment 601, 940-945. https://doi.org/10.1016/j. scitotenv.2017.05.211.

Alexander, D. D., Bailey, W. H., Perez, V., Mitchell, M.E., \& Su, S. (2013). Air ions and respiratory function outcomes: A comprehensive review. Journal of Negative Results in Biomedicine 12(14), 1-16. https://doi.org/10.1186/1477-5751-12-14.

Amin, N. D. M., Akasah, Z.A., \& Razzaly, W. (2015). Architectural evaluation of thermal comfort: Sick building syndrome symptoms in engineering education laboratories. ProcediaSocial and Behavioral Sciences 204, 19-28. Retrieved November 10, 2018, from http://www. sciencedirect.com/science/article/pii/S1877042815047539.

Ammann, H. M. (1988). Microbial volatile organic compounds. In J. M. Macher (Ed.) Bioaerosols: Assessment and Control, ACGIH, Cincinnati, UH, 1988 (pp. 26-1-26-17).

Andersen, I., Lundqvist, G. R., Jensen, P. L., \& Proctor, D. F. (1974). Human response to 78-hour exposure to dry air. Archives of Environmental Health: An International Journal 29(6), 319324.

Apte, M. G., Fisk, W. J., \& Daisey, J. M. (2000). Associations between indoor $\mathrm{CO}_{2}$ concentrations and sick building syndrome symptoms in U.S. Office buildings: An analysis of the 1994-1996 BASE study data. Indoor Air 10, 246-257. https://doi.org/10.1034/j.1600-0668.2000. 010004246.x.

Araki, A., Kawai, T., Eitaki, Y., Kanazawa, A., Morimoto K., Nakayama, K., et al. (2010). Relationship between selected indoor volatile organic compounds, so-called microbial VOC, and the prevalence of mucous membrane symptoms in single family homes. Science of the Total Environment 408(10), 2208-2215. https://doi.org/10.1016/j.scitotenv.2010.02.012.

ARB. (2012). Air Resources Board, Indoor air quality guideline. Retrieved November 10, 2018, from http://www.arb.ca.gov/research/indoor/formaldGL08-04.pdf.

ASHRAE Standard 62.1. (2004). Ventilation for acceptable indoor air quality, American Society of Heating, Refrigerating and Air Conditioning Engineers, Atlanta.

Augner, C., Hacker, G. W., \& Jekel, I. (2010). Geopathic stress zones: Short-term effects on work performance and well-being? The Journal of Alternative and Complementary Medicine 16(6), 657-661. Retrieved December 6, 2018, from https://www.ncbi.nlm.nih.gov/pubmed/20569033 , https://doi.org/10.1089/acm.2009.0499.

Aydogan, A., \& Montoya, L. D. (2011) Formaldehyde removal by common indoor plant species and various growing media. Atmospheric Environment 45(16), 2675-2682. Retrieved November 10, 2018, from https://www.sciencedirect.com/science/article/pii/ S1352231011002263, https://doi.org/10.1016/j.chemosphere.2018.01.078.

Awbi, H. B. (2003). Ventilation of buildings (2nd ed.). New York: Taylor \& Francis.

Bakó-Biró, Z., Clements-Croomea, D. J., Kochhara, N., Awbia, H. B., \& Williams, M. J. (2007). Ventilation rates in schools and learning performance. In Finnish Association of HVAC Societies. Proceedings of the 9th REHVA World Congress: Clima 2007 wellbeing indoors; Helsinki, 10-14 June 2007. Helsinki: Finnish Association of HVAC Societies.

Barna, E., \& Bánhidi, L. (2012). Combined effect of two local discomfort parameters studied with a thermal manikin and human subjects. Energy and Buildings 51, 234-241. https://doi.org/10. 1016/j.enbuild.2012.05.015.

Beauchemin, K. M., \& Hays, P. (1996). Sunny hospital rooms expedite recovery from severe and refractory depressions. Journal of Affective Disorders, 40(1-2), 49-51.

Benedetti, F., Colombo, C., Barbini, B., Campori, E., \& Smeraldi, E. (2001). Morning sunlight reduces length of hospitalization in bipolar depression. Journal of Affective Disorders 62(3), 221-223. https://doi.org/10.1016/S0165-0327(00)00149-X.

Bickford, M. (2005). Stress in the workplace: A general overview of the causes, the effects, and the solutions. Canadian Mental Health Association Newfoundland and Labrador Division.

Biology online. (2017). Bacteria. Retrieved November 11, 2018, from http://www.biology-online. org/dictionary/Bacteria. 
Blondel, A., \& Plaisance, H. (2011). Screening of formaldehyde indoor sources and quantification of their emission using a passive sampler. Building and Environment 46(6), 1284-1291. https://doi.org/10.1016/j.buildenv.2010.12.011.

Bornehag, C. G., Sundell, J, Weschler, C. J., Sigsgaard, T., Lundgren, B,, Hasselgren, M., et al. (2004). The association between asthma and allergic symptoms in children and phthalates in house dust: A nested case-control study. Environmental Health Perspectives 112, 1393-1397. https://doi.org/10.1289/ehp.7187.

Bowers, B., Flory, R., Ametepe, J., Staley, L., Patrick, A., \& Carrington, H. (2018). Controlled trial evaluation of exposure duration to negative air ions for the treatment of seasonal affective disorder. Psychiatry Research 259, 7-14. http://dx.doi.org/10.1016/j.psychres.2017.08.040.

Bullinger, M., Morfeld, M., von Mackensen, S., \& Brasche, S. (1999). The sick-building-syndrome- do women suffer more? Zentralblatt für Hygiene und Umweltmedizin 202(2-4), 235-241. http://dx.doi.org/10.1016/S0934-8859(99)80025-X.

Burge, P. S., Jones, P., \& Robertson, A. S. (1990). Sick building syndrome; environmental comparisons of sick and healthy buildings. Indoor Air 1, 479-83.

Burge, P. S. (2004). Sick building syndrome. Occupational and Environmental Medicine 61, 185190. http://dx.doi.org/10.1136/oem.2003.008813.

Butala, V., \& Novak, P. (1999). Energy consumption and potential energy savings in old school buildings. Energy and Buildings, 29(3), 241-246. https://doi.org/10.1016/S0378-7788(98) 00062-0.

CAN/CSA-Z1002-12. (2017). Occupational health and safety-Hazard identification and elimination and risk assessment and control.

Carrer, P., Wargocki, P., Fanetti, A., Bischof, W., Fernandes, E. D. O., Hartmann, T., et al. (2015) What does the scientific literature tell us about the ventilation-health relationship in public and residential buildings? Building and Environment 94(1), 273-286. Retrieved November 10, 2018, from http://www.sciencedirect.com/science/article/pii/ S0360132315300925, https://doi.org/10.1016/j.buildenv.2015.08.011.

CCOHS. (2011). Canadian centre for occupational health and safety. Environmental tobacco smoke (ETS): General information and health effects. Retrieved November 10, 2018, from http://www.ccohs.ca/oshanswers/psychosocial/ets_health.html.

CDC. (2009). Centers for disease control and prevention. Health risk appraisals. Retrieved November 10, 2018, from https://www.cdc.gov/workplacehealthpromotion/tools-resources/ workplace-health/assessment-tools.html.

CDC. (2013). Centers for Disease Control and Prevention. Indoor environmental quality. Retrieved November 10, 2017, from http://www.cdc.gov/niosh/topics/indoorenv/ chemicalsodors.html.

Chauhan, R. P., Kant, K., Sharma, S. K., \& Chakarvarti, S. K. (2003). Measurement of alpha radioactive air pollutants in fly ash brick dwellings. Radiation Measurements 36(1-6), 533536. Retrieved November 10, 2018, from http://www.sciencedirect.com/science/article/pii/ S1350448703001963, http://dx.doi.org/10.1016/S1350-4487(03)00196-3.

Choi, J. H., Beltran, L. O., \& Kim, H. S. (2012). Impacts of indoor daylight environments on patient average length of stay (ALOS) in a healthcare facility. Building and Environment 50, 65-75. http://dx.doi.org/10.1016/j.buildenv.2011.10.010.

Choi, H., Schmidbauer, N., \& Bornehag, C. G. (2017). Volatile organic compounds of possible microbial origin and their risks on childhood asthma and allergies within damp homes. Environment International, 98, 143-151. https://doi.org/10.1016/j.envint.2016.10.028.

Clark, L. A., \& Watson, D. J. (1988). Mood and the mundane: Relations between daily life events and self-reported mood. Journal of Personality and Social Psychology, 54(2), 296-308. https:// doi.org/10.1037/0022-3514.54.2.296.

Cohen, A., Janssen, S., \& Solomon, G. (2007). Hidden hazards of air fresheners. Natural Resources Defense Council. Clearing the Air, NRDC Issue Paper 2007, pp. 1-16. Retrieved November 10, 2018, from https://www.nrdc.org/health/home/airfresheners/airfresheners.pdf.

Collins. (2017a). Collins English Dictionary. Definition of 'health risk'. Retrieved November 10, 2018, from https://www.collinsdictionary.com/dictionary/english/health-risk. 
Collins. (2017b). Collins English Dictionary. Definition of 'health hazard'. Retrieved November 10, 2018, from, https://www.collinsdictionary.com/dictionary/english/health-hazard.

Commission Directive. (1999). Commission Directive 1999/77/EC of 26 July 1999 adapting to technical progress for the sixth time Annex I to Council Directive 76/769/EEC on the approximation of the laws, regulations and administrative provisions of the Member States relating to restrictions on the marketing and use of certain dangerous substances and preparations (asbestos). Retrieved November 10, 2018, from http://eur-lex.europa.eu/ LexUriServ/LexUriServ.do?uri=OJ:L:1999:207:0018:0020:EN:PDF.

Costa, M. F., \& Brickus, L. S. (2000). Effects of ventilation systems on prevalence of symptoms associated with sick buildings in Brazilian commercial establishments. Archives of Environmental Health, 55, 279-283. https://doi.org/10.1080/00039890009603419.

Crawford, J. O., \& Bolas, S. M. (1996). Sick building syndrome, work factors and occupational stress. Scandinavian Journal of Work, Environment \& Health, 22(4), 243-250. https://doi.org/ 10.5271/sjweh.138.

Crook, B., \& Burton, N. C. (2010). Indoor moulds, sick building syndrome and building related illness. Fungal Biology Reviews, 24(3-4), 106-113. https://doi.org/10.1016/j.fbr.2010.05.001.

Crump, K. S., Hoel, D. G., Langley, C. H., \& Peto, R. (1976). Fundamental carcinogenic processes and their implications for low dose risk assessment. Cancer Research 36(9 Part1), 2973-2979.

Dovjak, M., \& Kristl, Ž. (2009). Development of the Leonardo da Vinci accessible world for all respecting differences-AWARD project. International Journal of Sanitary Engineering Research, 2(3), 35-49.

Dovjak, M., \& Kristl, Ž. (2011). Health concerns of PVC materials in the built environment. International Journal of Sanitary Engineering Research, 5(1), 4-26.

Dovjak, M., Kukec, A. (2014). Prevention and control of sick building syndrome (SBS). Part 2, Design of a preventive and control strategy to lower the occurrence of SBS. International Journal of Sanitary Engineering Research 8(1), 41-55.

Easton, V. J., \& McColl, J. H. (1997). Statistics Glossary v1.1. Retrieved December 6, 2018, from, http://www.stats.gla.ac.uk/steps/glossary/.

EC European Commission. (2012). Recommendation from the Scientific Committee on Occupational Exposure. Retrieved November 10, 2018, from, http://ec.europa.eu/social/ BlobServlet?docId $=7722$ \&langId $=$ en.

ECA European Concerted Action. (1989). Indoor air quality \& its impact on man. COST Project 613. Environment and Quality of Life. Report No. 4. Sick Building Syndrome, A Practical Guide. Commission of the European Communities. Directorate General for Science, Research and Development. Joint Research Centre-Institute for the Environment. Luxembourg: Office for Publications of the European Communities. Retrieved November 10, 2018, from http:// www.buildingecology.com/publications/ECA_Report4.pdf.

EN 15251. (2007). Indoor environmental input parameters for design and assessment of energy performance of buildings addressing indoor air quality, thermal environment, lighting and acoustics.

Engvall, K., Norrby, C., Bandel, J., Hult, M., \& Norbäck, D. (2000). Development of a multiple regression model to identify multi-family residential buildings with a high prevalence of sick building syndrome (SBS). Indoor Air, 10, 101-110. https://doi.org/10.1034/j.1600-0668.2000. 010002101.x.

EPA. (2012). Environmental Protection Agency. Biological contaminants. Retrieved November 10, 2018, from http://www.epa.gov/iaq/biologic.html.

EPA. (2016). United States environmental protection agency. Risk assessment. Human Health Risk Assessment. Retrieved November 10, 2018, from https://www.epa.gov/risk/humanhealth-risk-assessment.

EPA. (2017a). Health risk of radon. Retrieved December 6, 2018, from https://www.epa.gov/ radon/health-risk-radon.

EPA. (2017b). Indoor Air Quality (IAQ) Volatile organic compounds' impact on indoor air quality. Retrieved November 10, 2018, from https://www.epa.gov/indoor-air-quality-iaq/ volatile-organic-compounds-impact-indoor-air-quality. 
Erdmann, C. A., Steiner, K. C., \& Apte, M. G. (2002). Indoor carbon dioxide concentrations and sick building syndrome symptoms. In The Base Study Revisited: Analyses of the 100 Building Dataset Proceedings: Indoor Air 2002, (pp. 443-448).

Erklavec, U., Dovjak, M., Golja, A., \& Kukec, A. (2017). Indoor air pollution and health effects: Systematic review. In 21st International Eco-Conference and 12th Eco-Conference on Environmental Protection of Urban and Suburban Settlements, Novi Sad, Serbia, 27th-29th September 2017 (pp. 39-47).

Eriksson, N. M., \& Stenberg, B. G. T. (2006). Baseline prevalence of symptoms related to indoor environment. Scandinavian Journal of Public Health, 34, 387-396. https://doi.org/10.1080/ 14034940500228281.

Freshwater, D. (1997). Geopathic stress. Complementary Therapies in Nursing and Midwifery, 3 (6), 160-162. Retrieved November 10, 2017, from http://www.sciencedirect.com/science/ article/pii/S1353611705810030, https://doi.org/10.1016/S1353-6117(05)81003-0.

$\mathrm{Fu}, \mathrm{X}$. (2016). Indoor microbial volatile organic compound (MVOC) levels and associations with respiratory health, sick building syndrome (SBS), and allergy fungi and mycotoxins risk assessment and management. In Environmental Mycology in Public Health, (pp. 387-395). Retrieved November 10, 2018, from http://www.sciencedirect.com/science/article/pii/ B9780124114715000223, https://doi.org/10.1016/B978-0-12-411471-5.00022-3.

Goodman, N. B., Steinemann, A., Wheeler, A. J., Paevere, P. J., Cheng, M., \& Browna, S. K. (2017). Volatile organic compounds within indoor environments in Australia. Building and Environment, 122, 116-125. https://doi.org/10.1016/j.buildenv.2017.05.033.

Gottesfeld, P. (2015). Time to ban lead in industrial paints and coatings. Front Public Health. 3, 144. Retrieved November 10, 2018, from https://www.ncbi.nlm.nih.gov/pmc/articles/ PMC4434842/, https://doi.org/10.3389/fpubh.2015.00144.

Hathaway, W. E., Hargreaves, J. A., Thomson, G. W., \& Novintsky, D. (1992). A summary of light related studies. A study into the effects of light on children of elementary school age. A Case of Daylight Robbery. IRC Internal Report 659, 11-27. Retrieved November 10, 2017, from http://www.naturallighting.com/cart/store.php?sc_page=62.

Hedge, A., Sterling, E. M., Collett, C. W., \& Mueller B (1987) Indoor air quality investigation as a psychological stressor. In Proceedings of the 4th Intern. Conf. on Indoor Air Quality and Climate, Indoor Air '87, Berlin (West) 17-21 August 1987 (vol. 2, pp. 552-556). Berlin: Inst. fur Wasser-, Boden- und Lufthygiene.

Hedge, A., \& Erickson, W. A. (1998). Sick building syndrome and office ergonomics: A targeted work environment analysis. Human Factors Laboratory, Department of Design \& Environmental Analysis, College of Human Ecology, Cornell University, Technology \& Engineering.

Heerwagen, J. H. (1986). The role of nature in the view from the window. In S. Zdepski, \& V. McCluney (Eds.) International Daylighting Conference Proceedings II, November 4-7, 1986. International Daylighting Organizing Committee, Long Beach, CA, pp. 430-437.

Hendrick, D. J., \& Lane, D. J. (1977). Occupational forrnalin asthma. British Journal of Industrial Medicine, 34, 11-18.

Hess-Kosa, K. (2002). Indoor air quality: The latest sampling and analytical methods, 2nd edn. CRC Press.

Heudorf, U., Mersch-Sundermann, V., \& Angerer, J. (2007). Phthalates: Toxicology and exposure. International Journal of Hygiene and Environmental Health, 210(5), 623-634. https://doi.org/ 10.1016/j.ijheh.2007.07.011.

Hodgson, M. J., Permar, E., Squire, G., Cagney, W., Allen, A., \& Parkinson, D. K. (1987). Vibrations as a cause of "tight-building syndrome" symptoms. Ibid 2, 449-453.

Hodgson, M. (2002). Indoor environmental exposures and symptoms. Environmental health perspectives, 110, 663-667. https://doi.org/10.1289/ehp.02110s4663.

HSA. (2017). Health and safety authority. healthy, safe and productive lives. Hazard and risk. Retrieved November 10, 2017, from http://www.hsa.ie/eng/Topics/Hazards/.

IARC. (2002). International agency for research on cancer. Monographs on the evaluation of carcinogenic risks to humans. In Man-Made Vitrous Fibres 2002 (vol. 81). IARC Press, Lyon. 
ILO. (2011). International Labour Organization. Indoor air ionization. Retrieved November 10, 2018, from http://www.ilo.org/oshenc/part-vi/indoor-environmental-control/item/261-indoorair-ionization.

ISO 7726. (1998). Ergonomics of the thermal environment-Instruments for measuring physical quantities.

Jaakkola, J. J. K., Heinonen, O. P., \& Seppänen, O. (1989). Sick building syndrome, sensation of dryness and thermal comfort in relation to room temperature in an office building: Need for individual control of temperature. Environment International, 15, 163-168. https://doi.org/10. 1016/0160-4120(89)90022-6.

Jaakkola, J. J., Oie, L., Nafstad, P., Botten, G., Samuelsen, S. O., \& Magnus, P. (1999). Interior surface materials in the home and development of bronchial obstruction in young children in Oslo, Norway. American Journal of Public Health, 89(2), 188-192. https://doi.org/10.2105/ AJPH.89.2.188.

Jaakkola, J. J. K., \& Knight, T. L. (2008). The role of exposure to phthalates from Polyvinyl Chloride products in the development of asthma and allergies: A systematic review and meta-analysis. Environmental Health Perspectives, 116(7), 845-853. https://doi.org/10.1289/ ehp.10846.

Jokl, M. V. (1989). Microenvironment, the theory and practice of indoor climate. Illinois: Charles C Thomas Pub Ltd.

Kameda, T., Takahashi, K., Kim, R., Jiang, Y., Movahed, M., Park, E.-K., et al. (2014). Bull World Health Organ 92(11), 790-797. Retrieved November 10, 2017, from https://www.ncbi. nlm.nih.gov/pmc/articles/PMC4221761/, http://dx.doi.org/10.2471/BLT.13.132118.

Kishi, R., Araki, A., Saitoh, I., Shibata, E., Morimoto, K., Nakayama, K., et al. (2012). Phthalate in house dust and its relation to sick building syndrome and allergic symptoms. In 30th International Congress on Occupational Health organized in Cancun from March 18th to March 23rd, 2012. Mexico: ICOH.

Korpi, A., Järnberg, J., \& Pasanen, A. L. (2009). Microbial volatile organic compounds. Critical Reviews in Toxicology, 39(2), 139-193. https://doi.org/10.1080/10408440802291497.

Kukec, A., Dovjak, M. (2014). Prevention and control of sick building syndrome (SBS). Part 1, Identification of risk factors. International Journal of Sanitary Engineering Research 8(1), 1640.

Lantz, P. M., Mendez, D., \& Philbert, M. (2013). Radon, smoking, and lung cancer: The need to refocus radon control policy. American Journal of Public Health 103(3), 443-447. Retrieved December 6, 2018, from https://www.ncbi.nlm.nih.gov/pmc/articles/PMC3673501/, http://dx. doi.org/10.2105/AJPH.2012.300926.

Lenvik, K. (1993). Smoking habits, atopy, and prevalence of sick building syndrome symptoms among office workers in Norway. Environment International, 19(4), 333-340. https://doi.org/ 10.1016/0160-4120(93)90125-2.

Li, C. S., Hsu, C. W., \& Lu, C. H. (1997). Dampness and respiratory symptoms among workers in day-care centers in a subtropical climate. Archives of Environmental Health, 52, 68-71. https:// doi.org/10.1080/00039899709603803.

Lim, F. L., Hashim, Z., Md Said, S., Than, L. T., Hashim, J. H., \& Norbäck, D. (2015). Sick building syndrome (SBS) among office workers in a Malaysian university-associations with atopy, fractional exhaled nitric oxide (FeNO) and the office environment. Science of the Total Environment, 1(536), 353-361. https://doi.org/10.1016/j.scitotenv.2015.06.137.

Liu, Y.-J., Mu, Y.-J., Zhu, Y.-G., Ding, H., \& Arens, N. C. (2007). Which ornamental plant species effectively remove benzene from indoor air? Atmospheric Environment 41(3), 650654. Retrieved November 10, 2018, from http://www.sciencedirect.com/science/article/pii/ S1352231006008077, http://dx.doi.org/10.1016/j.atmosenv.2006.08.001.

Logue, J. M., McKone, T. E., Sherman, M. H., \& Singer, B. C. (2011). Hazard assessment of chemical air contaminants measured in residences. Indoor Air, 21(2), 92-109. https://doi.org/ 10.1111/j.1600-0668.2010.00683.x. 
Lu, C. Y., Ma, Y. C., Lin, J. M., Li, C. Y., Lin, R. S., \& Sung, F. C. (2007). Oxidative stress associated with indoor air pollution and sick building syndrome-related symptoms among office workers in Taiwan. Inhalation Toxicology, 19(1), 57-65. https://doi.org/10.1080/ 08958370600985859 .

Madigan, M., \& Martinko, J. (Eds.). (2005). Brock biology of microorganisms (11th ed.). Upper Saddle River, NJ: Prentice Hall.

Markussen, S., \& Røed, K. (2014). Daylight and absenteeism-Evidence from Norway. Economics \& Human Biology, 16, 73-80. https://doi.org/10.1016/j.ehb.2014.01.002.

Marsili, D., Terracini, B., Santana, V. S., Ramos-Bonilla, J. P., Pasetto, R., Mazzeo, A., et al. (2016). Prevention of asbestos-related disease in countries currently using asbestos. International Journal of Environmental Research and Public Health 13(5), 494. Retrieved November 10, 2018, from https://www.ncbi.nlm.nih.gov/pmc/articles/PMC4881119/, http:// dx.doi.org/10.3390/ijerph13050494.

Mizoue, T., Reijula, K., \& Andersson, K. (2001). Environmental tobacco smoke exposure and overtime work as risk factors for sick building syndrome in Japan. American Journal of Epidemiology, 154(9), 803-808. https://doi.org/10.1093/aje/154.9.803.

Mølhave, L., Kjærgaard, S. K., \& Attermann, J. (2000). Sensory and other neurogenic effects of exposures to airborne office dust. Atmospheric Environment, 34(28), 4755-4766. https://doi. org/10.1016/S1352-2310(00)00266-1.

Mølhave, L. (2003). Organic compounds as indicators of air pollution. Indoor Air, 13(6), 12-19. https://doi.org/10.1034/j.1600-0668.13.s.6.2.x.

Morris, L., Hawkins, L. (1987). The role of stress in the sick building syndrome. In Proceedings of the 4th International Conference on Indoor Air Quality and Climate, Indoor Air '87, Berlin (West), 17-21 August 1987 (vol. 2, pp. 566-571). Berlin: Inst. fur Wasser, Boden und Lufthygiene.

Nakaoka, H., Todaka, E., Seto, H., Saito, I., Hanazato, M., Watanabe, M., et al. (2014). Correlating the symptoms of sick-building syndrome to indoor VOCs concentration levels and odour. Indoor and Built Environment, 23(6), 804-813. https://doi.org/10.1177/ $1420326 X 13500975$.

NDA. (2014). National Disability Authority. What is universal design. Retrieved November 10, 2018, from http://universaldesign.ie/What-is-Universal-Design/.

Nexo, E., Skov, P. G., \& Gravesen, S. (1983). Extreme fatique and malaise syndrome caused by badly-cleaned wall-to-wall carpets? Ecology of Disease, 2, 415-418.

Nicklas, M. H., \& Bailey, G. B. (1997). Analysis of the performance of students in daylight schools. In Proceedings of the 1997 Annual Conference, ASES (pp. 1-5). Colorado: American Solar Energy Society.

Nielsen, O. (1987). Man-made mineral fibers in the indoor climate caused by ceilings of man-made mineral wool. In B. Seifert, H. Esdorn, M. Fisher, H. Riiden, \& J. Wegner (Eds.) Proceedings of the 4th International Conference on Indoor Air Quality and Climate Indoor Air '87, (vol. 1, pp. 580-583). Berlin: Institute for Water, Soil and Air Hygiene.

NIH. (2017). National heart, lung, and blood institute. Risk factors. Retrieved November 10, 2018, from https://www.nhlbi.nih.gov/health/health-topics/topics/obe/risks.

NIOSH. (1976). National Institute for Occupational Safety and Health. Criteria for a recommended standard, occupational exposure to carbon dioxide. Retrieved November 10, 2018, from http:// www.cdc.gov/niosh/docs/1970/76-194.html.

NIPH. (2009). Nacionalni inštitut za varovanje zdravja RS, Osvežilci zraka. Retrieved November 10, 2018, from http://www.ivz.si/Mp.aspx?ni=78\&pi=6\&_6_id=286\&_6_PageIndex=0\&_6_ groupId=-2\&_6_newsCategory=IVZ+kategorija\&_6_action=ShowNewsFull\&pl=78-6.0.

Norbäck, D. (2009). An update on sick building syndrome: Personal risk factors for sick building syndrome. In Medscape, 2009. Retrieved November 10, 2018, from http://www.medscape.org/ viewarticle/701739_7. 
Norbäck, D., Hashim, J. H., Hashim, Z., \& Ali, F. (2017). Volatile organic compounds (VOC), formaldehyde and nitrogen dioxide $\left(\mathrm{NO}_{2}\right)$ in schools in Johor Bahru, Malaysia: Associations with rhinitis, ocular, throat and dermal symptoms, headache and fatigue. Science of the Total Environment, 592, 153-160. https://doi.org/10.1016/j.scitotenv.2017.02.215.

Nordström, K., Norbäck, D., \& Akselsson, R. (1994). Effect of air humidification on the sick building syndrome and perceived indoor air quality in hospitals: A four month longitudinal study. Occupational and Environmental Medicine 51(10), 683-688. Retrieved November 10, 2018, from https://www.ncbi.nlm.nih.gov/pmc/articles/PMC1128077/.

Norhidayah, A., Chia-Kuang, Lee, Azhar, M. K., \& Nurulwahida, S. (2013). Indoor air quality and sick building syndrome in three selected buildings. Procedia Engineering, 53, 93-98. https:// doi.org/10.1016/j.proeng.2013.02.014.

Norlen, U., Andersson, K. (1993). An indoor climate survey of the Swedish housing stock (the ELIB study). In Proceedings of Indoor Air'93, 6th International Conference on Indoor Air Quality and Climate, Helsinki (vo1. 1, pp. 743-748).

OJ RS. (2002). OJ RS No. 42/2002, 105/2002: Rules on the ventilation and air-conditioning of buildings.

Ooi, P. L., \& Goh, K. T. (1997). Sick building syndrome: An emerging stress-related disorder? International Journal of Epidemiology, 26(6), 1243-1249. https://doi.org/10.1093/ije/26.6. 1243.

OSHA. (2017). Occupational Safety and Health Administration. Health Hazard Definitions Regulations (Standards - 29 CFR) - Table of Contents. Retrieved November 10, 2018, from https://www.osha.gov/pls/oshaweb/owadisp.show_document?p_table=STANDARDS\&p_id= 10371.

Pantoja, L. D. M., Nascimento, R. F., \& Nunes, A. B. A. N. (2016). Investigation of fungal volatile organic compounds in hospital air. Atmospheric Pollution Research, 7(4), 659-663. https://doi. org/10.1016/j.apr.2016.02.011.

Park, S., Seo, J., \& Kim, J. T. (2015). A study on the application of sorptive building materials to reduce the concentration and volume of contaminants inhaled by occupants in office areas. Energy and Buildings 98, 10-18. Retrieved November 10, 2018, from http://www. sciencedirect.com/science/article/pii/S0378778815000195, http://dx.doi.org/10.1016/j.enbuild. 2014.12.056.

Petrović, E. K. (2017). 8-New and less recognized risks with building materials: Volatile organic compounds, replacement chemicals, and nanoparticles. Materials for a healthy, ecological and sustainable built environment. Principles for evaluation. A volume in Woodhead Publishing Series in Civil and Structural Engineering (pp. 191-202)

Pheasant, S. (1986). Body space: Anthropometry ergonomics and design. London: Taylor \& Francis.

Pheasant, S. (1987). Review of: "Ergonomics-standards and guidelines for designers" By Stephen Pheasant (London: BSI Standards, 1987). Ergonomics 31(8), 1214-1215.

Pheasant, S. (1991). Ergonomics, work and health (p. 358). London: MacMillan Press, Houndmills.

Porta, M. (2008). A dictionary of epidemiology (Sixth Edition). International Epidemiological Association, Oxford University Press. Retrieved November 10, 2018, from http://irea.ir/files/ site1/pages/dictionary.pdf.

Prek, M., \& Butala, V. (2012). An enhanced thermal comfort model based on the energy analysis approach. International Journal of Exergy, 10(2), 190-208. https://doi.org/10.1504/IJEX.2012. 045865 .

Redlich, C. A., Sparer, J., \& Cullen, M. R. (1997). Sick-building syndrome. Lancet, 349, 10131016. https://doi.org/10.1016/S0140-6736(96)07220-0.

Reilly, T., \& Stevenson, I. C. (1993). An investigation of the effects of negative air ions on responses to submaximal exercise at different times of day. Journal of Human Ergology, 22(1), $1-9$.

Robbins, C. L. (1986). Daylighting: Design and analysis (pp. 4-13). New York: Van Nostrand Reinhold Company. 
Robertson, A. S., Burge, P. S., Hedge, A., Wilson, S., \& HarrisBass, J. (1988). Relation between passive cigarette smoking exposure and "building sickness". Thorax, 43J, 2638.

Safeopedia. (2017). Health Hazard (OSHA). Retrieved November 10, 2018, from https://www. safeopedia.com/definition/4896/health-hazard-osha.

Sahlberg, B., Gunnbjörnsdottir, M., Soon, A., Jogi, R., Gislason, T., Wieslander, G., et al. (2013). Airborne molds and bacteria, microbial volatile organic compounds (MVOC), plasticizers and formaldehyde in dwellings in three North European cities in relation to sick building syndrome (SBS). Science of the Total Environment, 444, 433-440. https://doi.org/10.1016/j.scitotenv. 2012.10.114.

Sakai, K., Norbäck, D., Mi, S., Shibata, E., Kamijima, M., Yamada, T., et al. (2004). A comparison of indoor air pollutants in Japan and Sweden: Formaldehyde, nitrogen dioxide, and chlorinated volatile organic compounds. Environmental Research, 94(1), 75-85. https:// doi.org/10.1016/S0013-9351(03)00140-3.

Salthammer, T., Mentese, S., \& Marutzky, R. (2010). Formaldehyde in the Indoor Environment. Chemical Reviews, 110(4), 2536-2572. https://doi.org/10.1021/cr800399g.

Schneider, T., Sundell, J., Bischof, W., Bohgard, M., Cherrie, J. W., Clausen, P. A., et al. (2003). Airborne particles in the indoor environment. A European interdisciplinary review of scientific evidence on associations between exposure to particles in buildings and health effects. Indoor Air, 13, 38-48. https://doi.org/10.1034/j.1600-0668.2003.02025.x.

Seppänen, O. A., Fisk, W. J., \& Mendell, M. J. (1999). Association of ventilation rates and $\mathrm{CO}_{2}$ concentrations with health and other responses in commercial and industrial buildings. Indoor Air, 9, 226-252. https://doi.org/10.1111/j.1600-0668.1999.00003.x.

Seppänen, O., \& Fisk, W. J. (2002). Association of ventilation system type with SBS symptoms in office workers. Indoor air, 12, 98-112. https://doi.org/10.1034/j.1600-0668.2002.01111.x.

Simmons, L. H., \& Richard, J. L. (1997). Building materials: Dangerous properties of products. River Street: Wiley.

Stenberg, B., Eriksson, N., Höög, J., Sundell, J., \& Wall, S. (1994). The sick building syndrome (SBS) in office workers. A case-referent study of personal, psychosocial and building related risk indicators. International Journal of Epidemiology, 23, 1190-1197. https://doi.org/10.1093/ ije/23.6.1190.

Straus, D. C. (2009). Molds, mycotoxins, and sick building syndrome. Toxicology and Industrial Health, 25(9-10), 617-635. https://doi.org/10.1177/0748233709348287.

Subedi, B., Sullivan, K. D., \& Dhungana, B. (2017). Phthalate and non-phthalate plasticizers in indoor dust from childcare facilities, salons, and homes across the USA. Environmental Pollution, 230, 701-708. https://doi.org/10.1016/j.envpol.2017.07.028.

Sulman, F. G. (1980a). The effect of air ionization, electric fields, atmospherics and other electric phenomena on man and animal. Illinois: Thomas.

Sulman, F. G. (1980b). Migraine and headache due to weather and allied causes and its specific treatment. Upsala Journal of Medical Sciences. Supplement, 31, 41-44.

Sun, Y., Zhang, Y., Bao, L., Fan, Z., Wang, D., \& Sundell, J. (2013). Effects of gender and dormitory environment on sick building syndrome symptoms among college students in Tianjin, China. Building and Environment, 68, 134-139. https://doi.org/10.1016/j.buildenv. 2013.06.010.

Szumilas, M. (2010). Explaining odds ratios. Journal of the Canadian Academy of Child and Adolescent Psychiatry, 19(3), 227-229.

Šestan, P., Kristl, Ž., \& Dovjak, M. (2013). Formaldehyde in the built environment and its potential impact on human health. Gradbeni Vestnik, 62, 191-203.

Takigawa, T., Wang, B. L., Sakano, N., Wang, D. H., Ogino, K., \& Kishi, R. (2009). A longitudinal study of environmental risk factors for subjective symptoms associated with sick building syndrome in new dwellings. Science of the Total Environment, 407(19), 52235228. https://doi.org/10.1016/j.scitotenv.2009.06.023. 
Takigawa, T., Saijo, Y., Morimoto, K., Nakayama, K., Shibata, E., Tanaka, M., et al. (2012). A longitudinal study of aldehydes and volatile organic compounds associated with subjective symptoms related to sick building syndrome in new dwellings in Japan. Science of the Total Environment, 417-418, 61-67. https://doi.org/10.1016/j.scitotenv.2011.12.060.

Teeuw, K. B., Vandenbroucke-Grauls, C. M., \& Verhoef, J. (1994). Airborne gram-negative bacteria and endotoxin in sick building syndrome. A study in Dutch governmental office buildings. Archives of Internal Medicine 154(20), 2339-2345. http://dx.doi.org/10.1001/ archinte.154.20.2339.

Terman, M., Fairhurst, S., Perlman, B., Levitt, J., \& McCluney, R. (1986). Daylight deprivation and replenishment: A psychobiological problem with a naturalistic solution. In S. Zdepski, \& R. McCluney (Eds.) International Daylighting Conference Proceedings II, November 4-7, 1986 (pp. 438-443). Long Beach, CA: International Daylighting Organizing Committee.

Tsai, D. H., Lin, J. S., \& Chan, C. C. (2012). Office workers' sick building syndrome and indoor carbon dioxide concentrations. Journal of Occupational and Environmental Hygiene, 9(5), 345-351. https://doi.org/10.1080/15459624.2012.675291.

UNEP. (2016). Global report on the status of legal limits on lead in paint united nations environment programme 2016. Retrieved November 10, 2018, from https://wedocs.unep.org/ bitstream/handle/20.500.11822/11348/Limits-Lead-Paint-2016\%20Report-Final.pdf? sequence $=1 \&$ is Allowed $=\mathrm{y}$.

Valbjorn, O., \& Kousgaard, N. (1986). Headache and mucous membrane irritation at home and at work. Report 175. Harsholm: Statens Byggeforsknings lnstitut (SBI).

Valbjorn, O., \& Skov, P. (1987). The Danish Indoor climate study group. Influence of indoor climate on the sick building syndrome prevalence. In Proceedings of the 4th International Conference on Indoor Air Quality and Climate, Indoor air 1987, Berlin (West) 17-21 August 1987, (vol. 2, pp. 593-597). Berlin: Inst. fur Wasser, Boden und Lufthygiene.

Wang, S., Ang, H. M., \& Tade, M. O. (2007). Volatile organic compounds in indoor environment and photocatalytic oxidation: State of the art. Environment International, 33, 694-705. https:// doi.org/10.1016/j.envint.2007.02.011.

Wang, J., Li, B., Yang, Q., Yu, W., Wang, W., Norback, D., et al. (2013). Odors and sensations of humidity and dryness in relation to sick building syndrome and home environment in Chongqing, China. PLoS One, 8(8), e72385. https://doi.org/10.1371/journal.pone.0072385.

Webb. (2006). Considerations for lighting in the built environment: Non-visual effects of light. Retrieved November 10, 2018, from http://www.livingdaylights.nl/wp-content/uploads/2016/ 12/Webb-2006.-Considerations-for-lighting-in-the-built-envrionment-Non-visual-effects-oflight..pdf.

WHO. (2004). World Health Organisation. Electromagnetic hypersensitivity. Retrieved November 10, 2018, from http://www.who.int/peh-emf/publications/reports/EHS_Proceedings_June2006. pdf?ua $=1$.

WHO. (2009a). World Health Organization. Global health risks. Mortality and burden of disease attributable to selected major risks. Retrieved November 10, 2018, from http://www.who.int/ healthinfo/global_burden_disease/GlobalHealthRisks_report_full.pdf?ua=1\&ua=1.

WHO. (2009b). Night noise guidelines for Europe. Retrieved October 10, 2018, from http://www. euro.who.int/_data/assets/pdf_file/0017/43316/E92845.pdf?ua=1.

WHO. (2009c). World Health Organization. Dampness and mould. Retrieved November 10, 2018, from http://www.euro.who.int/_data/assets/pdf_file/0017/43325/E92645.pdf.

WHO. (2010). Childhood lead poisoning. Retrieved November 10, 2018, from http://www.who. $\mathrm{int} / \mathrm{ceh} /$ publications/leadguidance.pdf.

WHO. (2013). World Health Organisation. Environment and health. Retrieved November 10, 2018, from http://www.euro.who.int/en/health-topics/environment-and-health/noise.

WHO. (2014). World Health Organisation. Environment and health. Electromagnetic fields (EMF). Retrieved November 10, 2018, from http://www.who.int/peh-emf/about/WhatisEMF/ en/index $1 . h t m l$.

WHO. (2017a). Health Impact Assessment (HIA). The determinants of health. Retrieved November 10, 2018, from http://www.who.int/hia/evidence/doh/en/. 
WHO. (2017b). Health topics risk factors. Retrieved November 10, 2018, from http://www.who. int/topics/risk_factors/en/.

WHO. (2017c). International programme on chemical safety. Asbestos. Retrieved November 10, 2018, from http://www.who.int/ipcs/assessment/public_health/asbestos/en/.

Wolkoff, P. (1987). Sampling of VOC under conditions of high time resolution. In Proceedings of the 4th Intern. Conf. on Indoor Air Quality and Climate, Indoor Air '87, Berlin (West), 17-2I August 1987 (vol. 1, pp. 126-129). Berlin: Inst. fur Wasser, Boden und Lufthygiene.

Wonga, S. K. (2009). Sick building syndrome and perceived indoor environmental quality: A survey of apartment buildings in Hong Kong. Habitat International, 33(4), 463-471. https:// doi.org/10.1016/j.habitatint.2009.03.001.

Xu, Y., Hubal, E. A., Clausen, P. A., \& Little, J. C. (2009). Predicting residential exposure to phthalate plasticizer emitted from vinyl flooring: A mechanistic analysis. Environmental Science and Technology, 43(7), 2374-2380. https://doi.org/10.1021/es801354f.

Yassi, A., Kjellstrom, T., de Kok, T., \& Guidotti, T. (2001). Basic environmental health. New York: Oxford University Press Inc.

Yu, B. F., Hu, Z. B., Liu, M., Yang, H. L., Kong, Q. X., \& Liu, Y. H. (2009). Review of research on air-conditioning systems and indoor air quality control for human health. International Journal of Refrigeration, 32(1), 3-20. https://doi.org/10.1016/j.ijrefrig.2008.05.004.

Yu, C. W. F., \& Kim, J. T. (2012). Long-term impact of formaldehyde and VOC emissions from wood-based products on indoor environments and issues with recycled products. Indoor Built Environment, 21, 137-149. https://doi.org/10.1177/1420326X11424330.

Zhang, X., Zhao, Z., Nordquist, T., Larsson, L., Sebastian, A., \& Norback, D. (2011). A longitudinal study of sick building syndrome among pupils in relation to microbial components in dust in schools in China. Science of the Total Environment, 409(24), 52535259. https://doi.org/10.1016/j.scitotenv.2011.08.059.

Zhang, X., Sahlberg, B., Wieslander, G., Janson, C., Gislason, T., \& Norback, D. (2012). Dampness and moulds in workplace buildings: Associations with incidence and remission of sick building syndrome (SBS) and biomarkers of inflammation in a 10-year follow-up study. Science of the Total Environment, 430, 75-81. https://doi.org/10.1016/j.scitotenv.2012.04.040.

Zock, J., Zock, J. P., Plana, E., Jarvis, D., Antó, J. M., Kromhout, H., et al. (2007). The use of household cleaning sprays and adult asthma. American Journal of Respiratory and Critical Care Medicine, 176(8), 735-741. https://doi.org/10.1164/rccm.200612-1793OC.

Open Access This chapter is licensed under the terms of the Creative Commons Attribution 4.0 International License (http://creativecommons.org/licenses/by/4.0/), which permits use, sharing, adaptation, distribution and reproduction in any medium or format, as long as you give appropriate credit to the original author(s) and the source, provide a link to the Creative Commons license and indicate if changes were made.

The images or other third party material in this chapter are included in the chapter's Creative Commons license, unless indicated otherwise in a credit line to the material. If material is not included in the chapter's Creative Commons license and your intended use is not permitted by statutory regulation or exceeds the permitted use, you will need to obtain permission directly from the copyright holder.

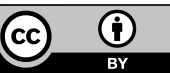

